\title{
NMDA Receptor Activation Suppresses Microtubule Growth and Spine Entry
}

\author{
Lukas C. Kapitein, ${ }^{1,2}$ Kah Wai Yau, ${ }^{1,2}$ Susana Montenegro Gouveia, ${ }^{3}$ Wouter A. van der Zwan, ${ }^{2}$ Phebe S. Wulf, ${ }^{1,2}$ \\ Nanda Keijzer, ${ }^{2}$ Jeroen Demmers, ${ }^{4}$ Jacek Jaworski, ${ }^{2,5}$ Anna Akhmanova, ${ }^{1,3}$ and Casper C. Hoogenraad ${ }^{1,2}$ \\ ${ }^{1}$ Cell Biology, Faculty of Science, Utrecht University, 3584CH Utrecht, The Netherlands, Departments of ${ }^{2}$ Neuroscience and ${ }^{3}$ Cell Biology and Genetics, \\ ${ }^{4}$ Proteomics Center, Erasmus Medical Center, 3015CE Rotterdam, The Netherlands, and 5International Institute of Molecular and Cell Biology, 02-109 \\ Warsaw, Poland
}

Dynamic microtubules are important to maintain neuronal morphology and function, but whether neuronal activity affects the organization of dynamic microtubules is unknown. Here, we show that a protocol to induce NMDA-dependent long-term depression (LTD) rapidly attenuates microtubule dynamics in primary rat hippocampal neurons, removing the microtubule-binding protein EB3 from the growing microtubule plus-ends in dendrites. This effect requires the entry of calcium and is mediated by activation of NR2B-containing NMDA-type glutamate receptor. The rapid NMDA effect is followed by a second, more prolonged response, during which EB3 accumulates along MAP2-positive microtubule bundles in the dendritic shaft. MAP2 is both required and sufficient for this activity-dependent redistribution of EB3. Importantly, NMDA receptor activation suppresses microtubule entry in dendritic spines, whereas overexpression of EB3-GFP prevents NMDA-induced spine shrinkage. These results suggest that short-lasting and long-lasting changes in dendritic microtubule dynamics are important determinants for NMDA-induced LTD.

\section{Introduction}

Most excitatory glutamatergic synapses in the mammalian brain are formed at tiny dendritic protrusions, named dendritic spines (Bourne and Harris, 2008). Dendritic spines play critical roles in synaptic function and exhibit a striking degree of structural plasticity, which is closely linked to changes in strength of synaptic connections (Holtmaat and Svoboda, 2009). Several studies have reported that glutamate receptor activation changes spine morphology by modulating postsynaptic cargo trafficking and actin cytoskeleton dynamics (Hotulainen and Hoogenraad, 2010). For example, it has been shown that enhanced actin polymerization induces spine enlargement during long-term potentiation (LTP) (Matsuzaki et al., 2004; Okamoto et al., 2004), whereas long-term

Received Nov. 29, 2010; revised April 13, 2011; accepted April 14, 2011.

Author contributions: L.C.K., A.A., and C.C.H. designed research; L.C.K., K.W.Y., S.M.G., W.A.v.d.Z., P.S.W., N.K., J.D., J.J., and C.C.H. performed research; L.C.K., K.W.Y., J.D., J.J., and C.C.H. analyzed data; L.C.K. and C.C.H. wrote the paper.

This work was supported by the Erasmus Medical Center (Erasmus Medical Center fellowship) and the Netherlands Organization for Scientific Research (NWO-VENI) (L.C.K.). J.J. is supported by a KNAL-Polish Academy of Sciences exchange fellowship and European Community FP7-HealthProt Grant 229676. S.M.G. is supported by Fundação para a Ciência e a Tecnologia fellowship. A.A. is supported by the Netherlands Organization for Scientific Research (NWO-ALW-VICI). C.C.H. is supported by the Netherlands Organization for Scientific Research (NWO-ALW$\mathrm{VICl}$ and NWO-CW), the Netherlands Organization for Health Research and Development (ZonMW-VIDI and ZonMWTOP), the European Science Foundation (European Young Investigator Award), European Molecular Biology Organization Young Investigators Program, and the Human Frontier Science Program (Human Frontier Science Program Career Development Award). We thank Dr. Roger Tsien for mCherry- $\alpha$-tubulin, Dr. Morgan Sheng for NR2A/B shRNAs, Dr. Nicole Leclerc for MAP2c constructs, Dr. Lester Binder for monoclonal antibodies AP-14 and AP-18 to MAP2, and Karel Bezstarosti for help with mass spectrometry analyses.

Correspondence should be addressed to Casper C. Hoogenraad, Cell Biology, Faculty of Science, Utrecht University, Kruytgebouw, Room N501, Padualaan 8, 3584CH Utrecht, The Netherlands. E-mail: c.hoogenraad@uu.nl.

DOI:10.1523/JNEUROSCI.6215-10.2011

Copyright $\odot 2011$ the authors $\quad 0270-6474 / 11 / 318194-16 \$ 15.00 / 0$ depression (LTD) involves spine shrinkage through actin depolymerization (Okamoto et al., 2004; Zhou et al., 2004). In contrast, the roles of microtubules and associated proteins in postsynaptic signaling mechanisms and their role in spine plasticity have remained mostly unexplored.

Both stable and dynamic microtubules are abundantly present in mature neurons (Jaworski et al., 2008; Conde and Cáceres, 2009; Hoogenraad and Bradke, 2009). In dendrites, microtubuleassociated protein 2 (MAP2) binds along the length of microtubules and its phosphorylation state is believed to regulate microtubule stability (Sánchez et al., 2000; Cassimeris and Spittle, 2001; Dehmelt and Halpain, 2005). Many reports have documented the close relationship between glutamate receptor activation and MAP2 alterations (Aoki and Siekevitz, 1985; Halpain and Greengard, 1990; Montoro et al., 1993; Quinlan and Halpain, 1996; Philpot et al., 1997). However, recent work has established an important role for dynamic microtubules in the maintenance of dendritic spines. Inhibition of microtubule growth or depletion of EB3, one of the major microtubule plusend binding proteins in mature neurons, caused the specific loss of mushroom-headed spines and increased the percentage of filopodia (Jaworski et al., 2009). Live imaging revealed that dynamic microtubules regularly depart from the dendritic shaft and enter dendritic spines (Gu et al., 2006; Hu et al., 2008; Jaworski et al., 2009) to stimulate actin polymerization and induce transient morphological changes, such as the formation of spine head protrusions or spine growth (Jaworski et al., 2009). These observations support a model in which EB3 plus-end decorated microtubules control actin dynamics and regulate spine morphology and synaptic plasticity. Nevertheless, little is known about the effect of glutamate receptor activation on the microtubule network. 
Here, we show that transient NMDA receptor activation induces sustained alterations in the microtubule network in dendrites. A chemical LTD protocol affects EB3 localization in hippocampal neurons in two phases: a fast phase $(>1 \mathrm{~min})$ leading to the loss of EB3 comets and a slow phase $(>10 \mathrm{~min})$ where EB3 binds along MAP2-positive microtubule bundles. MAP2 directly interacts with EB3 and is essential for the spatial redistribution of EB3 along the dendritic microtubules. NMDA receptor activation also suppresses microtubule entry in dendritic spines, whereas overexpression of EB3-GFP prevents LTD-induced spine shrinkage. These results demonstrate that excitatory stimuli can alter the cytoskeletal organization in dendrite branches and spines by directly affecting microtubule dynamics.

\section{Materials and Methods}

\section{Antibodies and reagents}

The following primary and secondary antibodies were used in this study: rabbit anti-EB3 (02-1005-07) (Stepanova et al., 2003; Jaworski et al., 2009), mouse anti-MAP2 (AP14; AP118) (Kalcheva et al., 1994), mouse anti-tau, mouse anti- $\beta$-actin (Millipore Bioscience Research Reagents), rabbit anti-GFP (Abcam; 1:1000), mouse anti-MAP2 (HM-2), mouse anti- $\alpha$-tubulin, mouse anti-acetylated tubulin (Sigma-Aldrich), mouse anti-bassoon (Nventa Biopharmaceuticals), rabbit anti- $\beta$-galactosidase (MP Biomedicals), mouse anti- $\beta$-galactosidase (Promega), rabbit anti-HA, mouse anti-Myc, rabbit anti-GFP (Medical and Biological Laboratories), mouse class III $\beta$-tubulin antibody (Tuji; Covance), mouse anti-GFP (Quantum), and Alexa 488-, Alexa 568-, and Alexa 630-conjugated secondary antibodies (Invitrogen).

Other reagents used in this study include nocodazole, DL-2-amino-5phosphonopentanoic acid (APV), 6-cyano-7-nitroquinoxaline-2,3-dione (CNQX), glycine, NMDA, AMPA, tetrodotoxin (TTX), bicuculline, $\alpha$-(4hydroxyphenyl)- $\beta$-methyl-4-benzyl-1-piperidineethanol (ifenprodil), $\alpha$-(4-hydroxyphenyl)- $\beta$-methyl-4-(phenylmethyl)-1-piperidinepropanol hydrochloride (Ro 25-6981), 1,2-bis(2-aminophenoxy)ethane- $N, N, N^{\prime}, N^{\prime}$ tetraacetic acid tetrakis(acetoxymethyl ester) (BAPTA-AM), 1-amino-1,3cyclopentanedicarboxylic acid (ACPD), 2-amino-4-phosphonobutyric acid (4-AP), okadaic acid and staurosporine (Sigma-Aldrich), and microtubuleassociated protein fraction (Cytoskeleton).

\section{Expression constructs}

The following mammalian expression plasmids have been described: pGW1-EB3-GFP (Jaworski et al., 2009), pGW1-GFP, p $\beta$ actin-HA- $\beta$ galactosidase (Hoogenraad et al., 2005), pSuper vector (Brummelkamp et al., 2002), pSuper-EB3-shRNA (Jaworski et al., 2009), GFP-MAP2c (Farah et al., 2005), NR2B-shRNA and NR2A-shRNAs (Kim et al., 2005), mCherry- $\alpha$-tubulin (Shaner et al., 2004), and GST-EB3 (Komarova et al., 2005). GFP-KIFC2 was generated by PCR cloning full-length rat KIFC2 cDNA into pEGFP-C1. The MAP2\#1 shRNA sequence (cagggcacctattcagata) and MAP2\#2 shRNA sequence (ttcgctgagcctttagaca) targeting rat MAP2 mRNA was designed based on the experimentally verified sequences (Krichevsky and Kosik, 2002; Fontaine-Lenoir et al., 2006). The complementary oligonucleotides were annealed and inserted into pSuper vector.

\section{Primary hippocampal neuron cultures, transfection, infection,} and immunohistochemistry

Primary hippocampal cultures were prepared from embryonic day 18 rat brains (Banker and Goslin, 1998; Kapitein et al., 2010). Cells were plated on coverslips coated with poly-L-lysine $(30 \mu \mathrm{g} / \mathrm{ml})$ and laminin $(2 \mu \mathrm{g} /$ $\mathrm{ml}$ ) at a density of $75,000 /$ well. Hippocampal cultures were grown in Neurobasal medium (NB) supplemented with B27, $0.5 \mathrm{~mm}$ glutamine, $12.5 \mu \mathrm{M}$ glutamate, and penicillin/streptomycin. Hippocampal neurons were transfected using Lipofectamine 2000 (Invitrogen). Briefly, DNA (3.6 $\mu \mathrm{g} /$ well) was mixed with $3 \mu \mathrm{l}$ of Lipofectamine 2000 in $200 \mu \mathrm{l}$ of NB, incubated for $30 \mathrm{~min}$, and then added to the neurons in $\mathrm{NB}$ at $37^{\circ} \mathrm{C}$ in $5 \%$ $\mathrm{CO}_{2}$ for $45 \mathrm{~min}$. Next, neurons were washed with $\mathrm{NB}$ and transferred in the original medium at $37^{\circ} \mathrm{C}$ in $5 \% \mathrm{CO}_{2}$ for $2-4 \mathrm{~d}$.
To express EB3-GFP in cultured hippocampal neurons, we used Semliki Forest virus (SFV)-mediated gene delivery. The EB3-GFP construct was cloned into the pSFV2 vector and packaged into SFV replicons as described previously (Jaworski et al., 2009). In short, SFV-replicons were harvested $24 \mathrm{~h}$ after transfection of helper and pSFV2-EB3 vector RNA into baby hamster kidney-21 cells, filter-sterilized, activated with $\alpha$-chymotrypsine (Sigma-Aldrich), and concentrated by ultracentrifugation. Virus titer was determined by infection of BHK-21 cell with serial dilutions, followed by fluorescence examination at $18-24 \mathrm{~h}$ after infection. Cultured hippocampal neurons were infected at DIV21 by the addition of $1 \mu \mathrm{l}\left(\sim 10^{7}\right.$ replicons $\left./ \mathrm{ml}\right)$ of SFV infectious replicons to the cultures at least $4 \mathrm{~h}$ before live-cell imaging.

For immunohistochemistry, neurons were fixed for 5 min with icecold $100 \%$ methanol $/ 1 \mathrm{~mm}$ EGTA at $-20^{\circ} \mathrm{C}$, followed by 5 min with $4 \%$ formaldehyde $/ 4 \%$ sucrose in PBS at room temperature. After fixation, cells were washed two times in PBS for $30 \mathrm{~min}$ at room temperature, and incubated with primary antibodies in GDB buffer $(0.2 \%$ BSA, $0.8 \mathrm{M}$ $\mathrm{NaCl}, 0.5 \%$ Triton X-100, $30 \mathrm{~mm}$ phosphate buffer, $\mathrm{pH}$ 7.4) overnight at $4^{\circ} \mathrm{C}$. Neurons were then washed three times in PBS for $5 \mathrm{~min}$ at room temperature and incubated with Alexa-conjugated secondary antibodies in GDB for $2 \mathrm{~h}$ at room temperature and washed three times in PBS for 5 min. Slides were mounted using Vectashield mounting medium (Vector Laboratories). Confocal images were acquired using a LSM510 confocal microscope (Zeiss) with a $40 \times$ or $63 \times$ oil objective.

\section{GST pull-down assays}

GST fusions of EB3 expression and purification of the GST-tagged proteins from Escherichia coli and Western blotting was performed as described previously (Komarova et al., 2005). GFP-MAP2c and GFPKIFC2 constructs were expressed in HEK293 cells for 24 h, lysates were prepared in a lysis buffer containing $20 \mathrm{~mm}$ Tris-HCl, pH 7.5, $100 \mathrm{~mm}$ $\mathrm{NaCl}, 1 \%$ Triton X-100, 1 mm DTT, and protease inhibitors (Complete; Roche), and mixed with GST-fusion proteins. Brains were obtained from adult female rats and homogenized in $10 \times$ volume/weight in the same lysis buffer. Brain lysates were centrifuged at $16,000 \times g$ for $15 \mathrm{~min}$ at $4^{\circ} \mathrm{C}$, and the supernatant was incubated with individual GST fusion proteins for $2 \mathrm{~h}$ at $4^{\circ} \mathrm{C}$. Beads were washed four times with a buffer containing 20 mм Tris-HCl, pH 8, $150 \mathrm{~mm} \mathrm{NaCl}, 0.05 \%$ Triton X-100, and 1 mм DTT. The proteins retained on the beads were analyzed by Western blotting (GFP expression constructs) or mass spectrometry (brain lysates).

\section{Mass spectrometry analysis}

For mass spectrometry analysis, proteins bound to the beads were separated on a 3-8\% NuPAGE Tris-acetate gel and stained with the Colloidal Blue staining kit (Invitrogen). Gel lanes were cut into $2 \mathrm{~mm}$ slices using an automatic gel slicer and subjected to in-gel reduction with dithiothreitol, alkylation with iodoacetamide, and digestion with trypsin (Promega; sequencing grade), essentially as described previously (Wilm et al., 1996). Nanoflow liquid chromatography (LC)/MS/MS was performed on an 1100 series capillary LC system (Agilent Technologies) coupled to a linear trap quadrupole linear ion trap mass spectrometer (Thermo Fisher Scientific) operating in positive mode and equipped with a nanospray source. Peptide mixtures were trapped on a ReproSil C18 reversedphase column (Dr. Maisch GmbH; column dimensions, $1.5 \mathrm{~cm} \times 100$ $\mu \mathrm{m}$; packed in-house) at a flow rate of $8 \mu \mathrm{l} / \mathrm{min}$. Peptide separation was performed on ReproSil C18 reversed-phase column (Dr. Maisch GmbH; column dimensions, $15 \mathrm{~cm} \times 50 \mu \mathrm{m}$; packed in-house) using a linear gradient from 0 to $80 \% \mathrm{~B}$ [A, $0.1 \mathrm{~m}$ acetic acid; B, $80 \%$ (v/v) acetonitrile, $0.1 \mathrm{M}$ acetic acid] in $70 \mathrm{~min}$ and at a constant flow rate of $200 \mathrm{nl} / \mathrm{min}$ using a splitter. The column eluent was directly sprayed into the electrospray ionization source of the mass spectrometer. Mass spectra were acquired in continuum mode; fragmentation of the four peptides was performed in data-dependent mode. Peak lists were automatically created from raw data files using the Mascot Distiller software (version 2.1; Matrix Science). The Mascot search algorithm (version 2.1; Matrix Science) was used for searching against the NCBInr database (release NCBInr_20070217; taxonomy, Rattus norvegicus). The peptide tolerance was typically set to 2 $\mathrm{Da}$ and the fragment ion tolerance to $0.8 \mathrm{Da}$. A maximum number of two missed cleavages by trypsin was allowed, and carbamidomethylated cys- 
teine and oxidized methionine were set as fixed and variable modifications, respectively. The Mascot score cutoff value for a positive protein hit was set to 60. Individual peptide MS/MS spectra with Mowse scores $<40$ were checked manually and either interpreted as valid identifications or discarded.

Total internal reflection fluorescence and spinning disk microscopy and image processing

Total internal reflection fluorescence microscopy (TIRFM) was performed as described previously (Jaworski et al., 2009; Kapitein et al., 2010) on an inverted research microscope (Nikon Eclipse TE2000E; Nikon) with a CFI Apo TIRF 100×, 1.49 numerical aperture (NA), oil objective (Nikon), equipped with Coolsnap HQ CCD cameras (Photometrics).

To perform live-cell spinning disk confocal microscopy, we use a Nikon Eclipse-Ti (Nikon) microscope with a CFI Apo TIRF 100×, 1.49 NA, oil objective (Nikon). The microscope is equipped with a motorized stage (ASI; PZ-2000) and Perfect Focus System (Nikon) and uses MetaMorph 7.6.4 software (Molecular Devices) to control the cameras and all motorized parts. Confocal excitation and detection is achieved using a 50 mW $491 \mathrm{~nm}$ laser (Cobolt Calypso) and a Yokogawa spinning disk confocal scanning unit (CSU-X1-A1N-E; Roper Scientific) equipped with a triple-band dichroic mirror (z405/488/568trans-pc; Chroma) and a filter wheel (CSUX1-FW-06P-01; Roper Scientific) containing a GFP emission filter (ET525/50m; Chroma). Confocal images were acquired with a QuantEM:512 SC EMCCD camera (Photometrics) at a final magnification of $68 \mathrm{~nm} /$ pixel, including the additional $2.5 \times$ magnification introduced by an additional lens mounted between scanning unit and camera (VM Lens C-2.5X; Nikon). All imaging was performed in full conditioned medium and a small incubator system (Tokai Hit; INUG2ZILCS-H2) is used on this system to maintain neuronal health (Kapitein et al., 2010).

For chemical LTD, NMDA was added to a final concentration of $50 \mu \mathrm{M}$ during the time-lapse recordings. In control experiments, $200 \mu \mathrm{M}$ APV was also present for at least $1 \mathrm{~h}$ before addition of NMDA. For glycine and $\mathrm{KCl} /$ chemical LTP treatments, neurons were transferred to HEPESbuffered extracellular solution (ECS) (10 mm HEPES, $150 \mathrm{~mm} \mathrm{NaCl}, 5$ $\mathrm{mm} \mathrm{KCl,} 2 \mathrm{~mm} \mathrm{CaCl}_{2}$, $30 \mathrm{~mm}$ glucose, $\mathrm{pH}$ 7.4) containing $20 \mu \mathrm{m}$ bicuculline 10 min before imaging (Lu et al., 2001; Park et al., 2006). During imaging, $\mathrm{KCl}$ and glycine were added to final concentrations of $50 \mathrm{~mm}$ and $200 \mu \mathrm{M}$, respectively, for $1 \mathrm{~min}$ and subsequently replaced with the original ECS. For local stimulation, a micropipette filled with $100 \mu \mathrm{M}$ NMDA and $10 \mu \mathrm{M}$ glycine (Rose et al., 2009) was positioned very close to the dendrite and a single $20 \mathrm{~s}$ pressure ejection of 30 psi was generated using a Femtojet express microinjector (Eppendorf).

Images of live cells were processed and analyzed using MetaMorph, Adobe Photoshop, or LabVIEW (National Instruments) software. To analyze comet numbers during chemical treatments, comets numbers were obtained from binarized images generated by thresholding images that were first convoluted with the Mexican hat-type kernel described by Mashanov and Molloy (2007) to enhance fluorescent particles and remove background fluorescence. Dendritic area was determined in MetaMorph by inclusive, binary, thresholding images down to $\sim 30 \%$. Spine entry events were identified from maximum and average projections of entire time-lapse recordings, as shown in Figure 11A-F.

\section{Image analysis and quantification}

Morphometric analyses of dendritic protrusions of fixed hippocampal neurons. For the morphometric analysis of dendritic protrusions, we used $\beta$-gal, GFP, or mRFP as an unbiased cell fill. Because protrusions often crossed several $z$ planes, we took series stacks from the bottom to the top of all dendrites and used the LSM software to generate image projections for quantitative analyses. Images were not further processed and were of similar high quality to the original single planes. The number of planes, typically six to eight, was chosen to cover the entire dendrite from top to bottom. All experiments were repeated at least three times with an $n>7$ for individual experiments were analyzed in a double-blind manner. Between 150 and 300 protrusions were scored for every neuron and expressed per $10 \mu \mathrm{m}$ length of dendrite. Discrimination was made between filopodia-like protrusions and mushroom-shaped spines; mea- surements of length and width of the protrusions were performed as described previously (Jaworski et al., 2009) and were classified based on the ratio of spine head width to protrusion length according to the following ratios: the spine whose width was equal to or more than one-half the size of its length was judged as standard mushroom spine. The protrusion whose width was smaller than one-half the size of its length was judged as filopodia or thin spine (Jaworski et al., 2009). In those cases in which the total length of the spine could not be adequately seen or its length was $>5 \mu \mathrm{m}$, protrusions were excluded from analysis.

Quantification of EB3 distribution in dendrites and axons. Measurements of endogenous EB3 and EB3-GFP localization in fixed neurons were performed as described previously (Jaworski et al., 2009). The number of EB3 comets per $10 \mu \mathrm{m}$ of axon/dendrite length, the length of the EB3 comets, and average fluorescent intensity of EB3 signals in the cell body, dendrites, and axons were measured using MetaMorph software. The dendrites and axons of GFP-expressing neurons were identified based on their morphology and by immunostaining for the dendritic marker MAP2 and axonal marker tau. Statistical analysis was performed with Student's $t$ test assuming a two-tailed and unequal variation. $N$ was defined as the number of transfected neurons.

\section{Results}

\section{Glutamate receptor activation affects EB3 distribution}

To determine how glutamate stimulation affects microtubule organization in primary cultures of rat hippocampal neurons, we examined the distribution of dynamic microtubules using antibodies that recognize the microtubule plus-end binding protein EB3 (Stepanova et al., 2003; Jaworski et al., 2009). Without stimulation, EB3 in fully differentiated neurons $(>14 \mathrm{~d}$ in vitro; DIV14) was found in comet-like structures corresponding to growing microtubule plus tips throughout the cell body, axon, and dendritic shaft and occasionally in spines that colocalize with synaptic markers (Fig. 1A) (Jaworski et al., 2009). On average, $6.6 \pm 0.5 \mathrm{~EB} 3$ comets per $10 \mu \mathrm{m}$ primary dendrite were observed (Fig. 1C). We next examined the localization of EB3 on bath application of $50 \mu \mathrm{M}$ glutamate to maximize the number of synapses undergoing plasticity. On treatment with $50 \mu \mathrm{M}$ glutamate for $5 \mathrm{~min}$, the characteristic EB3 comet-like staining was strongly decreased and replaced by a diffuse cytoplasmic signal within the dendrites (Fig. $1 B$ ). Interestingly, the EB3 staining in tau-positive axons was unaffected (Fig. $1 B, E$ ).

Quantification of these observations for different time intervals of glutamate stimulation revealed that a striking decrease in the number of dendritic EB3-positive comets already occurred within 1-2 min after application of $50 \mu \mathrm{m}$ glutamate (Fig. $1 C, D$ ). The maximal effect, $\mathrm{a}>20$-fold decrease in the number of comets per $10 \mu \mathrm{m}$ primary dendrite, was observed after $5 \mathrm{~min}$ of exposure to glutamate (Fig. $1 D$ ). Dose-response experiments revealed that glutamate-induced comet removal was concentration dependent, with $30 \mu \mathrm{M}$ glutamate already removing $\sim 70 \%$ of the EB3 comets in dendrites. The glutamate-induced redistribution of EB3 was not associated with changes in the localization of presynaptic protein bassoon (Fig. $1 A, B$ ) and postsynaptic protein PSD-95 (data not shown) staining, indicating that glutamate caused a rapid redistribution of EB3 without affecting synaptic markers. Moreover, we never observed focal swellings along the dendrites, vacuole-like structures, or abnormal MAP2 distribution that emerge after excessive glutamate receptor stimulation (Fig. 1 A,B) (Faddis et al., 1997; Hoskison et al., 2007), indicating that the EB3 redistribution is not attributable to excitotoxicity.

\section{Glutamate induces EB3 translocation through $\mathrm{Ca}^{2+}$ influx and NMDA receptors}

Glutamate acts via ionotropic glutamate receptors that include the AMPA-type receptor, kainate (KA) receptor, and the NMDA- 
A
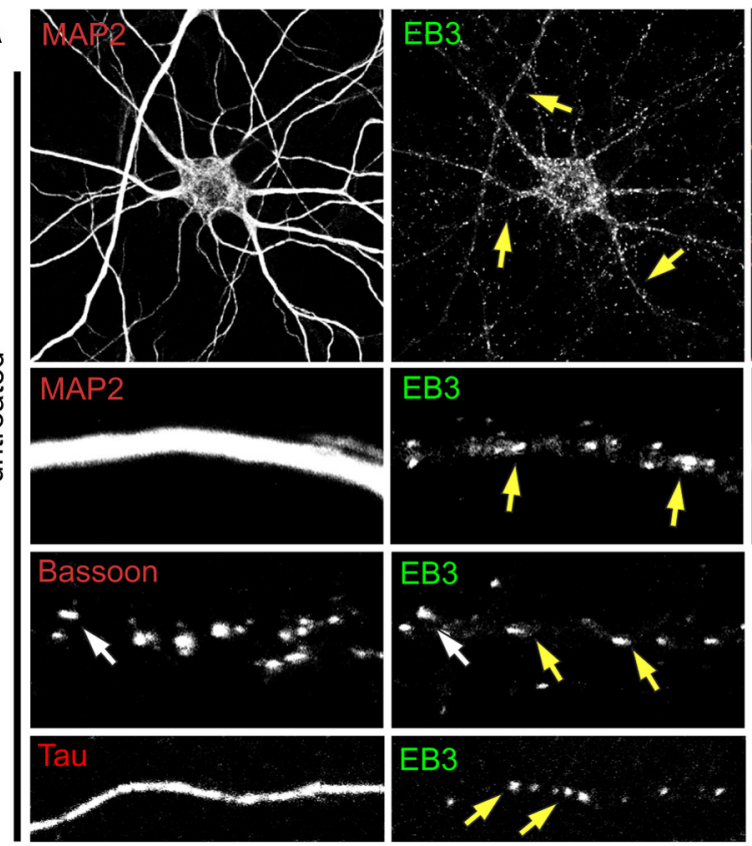

B
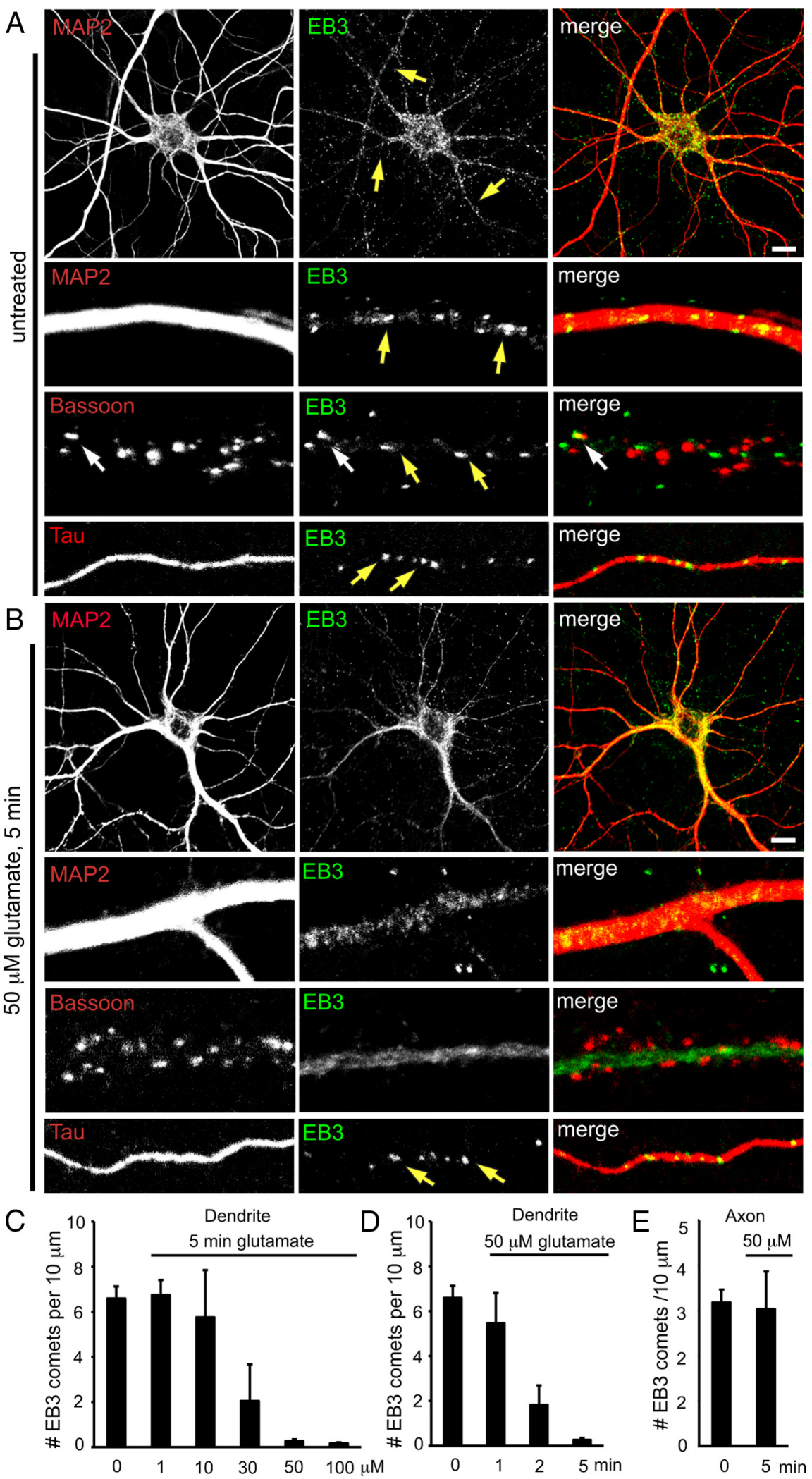

Figure 1. Glutamate receptor activation affect $E B 3$ localization. $\boldsymbol{A}, \boldsymbol{B}$, Representative images of rat hippocampal neurons (DIV17) untreated $(\boldsymbol{A})$ or treated with $50 \mu \mathrm{m}$ glutamate for $5 \mathrm{~min}(\boldsymbol{B})$ and double-labeled with rabbit anti-EB3 antibody (green) and mouse anti-MAP2 antibody (red). Only the merge is shown in color. Neuronal segments (bottom panels) are enlarged to show the localization of EB3 in dendrites (MAP2), axons (tau), and near synapses (bassoon). The yellow arrows indicate endogenous EB3 comet-like staining. After stimulation, EB3 comets are strongly decreased and replaced by a diffuse cytoplasmic signal within the dendrites. Scale bar, 10 $\mu \mathrm{m}$. C, D, Quantification of the number of EB3 comets per $10 \mu$ m dendrite (mean \pm SEM) of hippocampal neurons stimulated with various concentrations of glutamate for $5 \mathrm{~min}(\boldsymbol{C})$ or $50 \mu \mathrm{m}$ glutamate for various time intervals (D).E, Quantification of the number of EB3 comets per 10 $\mu \mathrm{m}$ axon (mean \pm SEM) of hippocampal neurons untreated (0) or stimulated with $50 \mu \mathrm{m}$ glutamate for 5 min. type receptor as well as mGluRs (Hollmann and Heinemann, 1994; Dingledine et al., 1999). To determine which glutamate receptor classes mediated the redistribution of EB3, we treated the cultures with a variety of subtype-selective glutamate receptor agonists and antagonists (Fig. 2A-F). Blocking NMDA receptors with the antagonists APV or MK-801 greatly reduced the EB3 redistribution on stimulation with $100 \mu \mathrm{M}$ glutamate (Fig. $2 A, D$ ) (data not shown). In contrast, blocking either AMPA/KA receptors (CNQX) or metabotropic glutamate receptors [AIDA (1-aminoindan-1,5dicarboxylic acid)], or both together, did not inhibit the glutamate-induced EB3 relocalization (Fig. $2 A, D$ ). The NMDA receptor specificity of this effect was confirmed by using a chemical LTD protocol (Kameyama et al., 1998; Lee et al., 1998; Beattie et al., 2000; Ehlers, 2000; Colledge et al., 2003), whereby cells were treated with NMDA itself. Bath application of $50 \mu \mathrm{M}$ NMDA for $5 \mathrm{~min}$ strongly decreased the number of dendritic EB3-positive comets in all cells examined (Fig. $2 B, E$ ), which could be blocked by APV and MK-801 (Fig. 2C,F) (data not shown). Stimulating cells with the metabotropic glutamate receptor agonist ACPD or AMPA glutamate receptor agonist AMPA was ineffective (Fig. $2 B, E$ ). The decrease in the proportion of dendritic EB3-positive comets also occurred after shorter NMDA incubation times, within 1-2 min after NMDA application (Fig. $3 A, C$ ). Similar results were obtained with lower concentrations of NMDA and $10 \mu \mathrm{M}$ NMDA already removed most of the EB3 comets in dendrites (Fig. $3 B, D)$. The disappearance of EB3-positive comets was not attributable to the degradation of the protein, because immunoblot analysis showed unchanged levels of total EB3 in NMDA-stimulated cultures, independent of concentration and time of the treatment (Fig. 3E,F). These results demonstrate that a classic chemical LTD protocol induces the redistribution of the microtubule plus-end binding protein EB3 after NMDA receptor activation.

Calcium influx into the postsynapse is considered a critical event in NMDAdependent signaling in the hippocampus (Collingridge et al., 2004; Lau and Zukin, 2007). Indeed, the EB3 redistribution was dependent on calcium levels, as addition of the intracellular calcium chelator BAPTA-AM blocked the NMDA effect (Fig. 2A,D). To test whether $\mathrm{EB} 3$ redistributes in response to other NMDA/calcium-dependent signaling pathways, we used chemical LTP stimulation (glycine/KCl) (Lu et al., 2001; Park et al., 2004) and network disinhibition protocols (bicuculline/4-AP) (Tapia et al., 1999; 
Hardingham et al., 2002). Exposure of neurons to glycine/ $\mathrm{KCl}$ or bicuculline/ 4-AP for short time periods, 5 or $15 \mathrm{~min}$, respectively, did not cause any obvious changes in the distribution of endogenous EB3 (data not shown). However, after $24 \mathrm{~h}$ bicuculline/4-AP treatment, approximately one-half of the neurons showed significant loss of dendritic EB3 comets (Fig. $2 B, E$ ), an effect that was blocked by NMDA receptor antagonist APV. These data suggest that, in addition to chemical LTD, prolonged elevations in electrical activity can also affect EB3 localization.

In mature hippocampal neuron cultures, calcium-dependent signaling through NMDA receptors mainly occurs through either NR2A- or NR2Bcontaining receptors (Cull-Candy et al., 2001; Lau and Zukin, 2007). RNA interference experiments using DNA (pSuper)-based constructs that reduce the expression of endogenous NR2A and/or NR2B (Kim et al., 2005) showed that knockdown of NR2B rather than NR2A blocked the glutamate-dependent EB3 redistribution (Fig. 2C). Consistently, no effect on EB3 was found when selective NR2B-containing NMDA receptor blockers ifenprodil and Ro 25-6981 were used during the stimulation (Fig. $2 C, F)$. Together, these data demonstrate that NMDA stimulates EB3 translocation via calcium influx through NR2Bcontaining NMDA receptors.

NMDA receptor activation attenuates microtubule growth To investigate EB3 redistribution dynamics, we performed timelapse imaging of GFP-tagged EB3, expressed using a SFV-based vector, in live hippocampal neurons. In dendrites, exogenous EB3-GFP labeled growing microtubule plus-ends and both retrograde and anterograde displacements of EB3-GFP comets were observed (Fig. 4A-C). In addition, diffuse EB3-GFP signals with lower intensity were observed throughout the dendritic shaft. Although EB3-GFP comets were very dynamic, their overall distribution in unstimulated neurons was constant over time (Fig. $4 A, B$ ), as previously published (Stepanova et al., 2003; Jaworski et al., 2009). We observed on average $1.02 \pm 0.03$ comets per 10 $\mu \mathrm{m}^{2}$, which moved at an average growth velocity of $0.12 \pm 0.03$ $\mu \mathrm{m} / \mathrm{s}$. Consistent with the immunohistochemical data, NMDA stimulation induced a strong and rapid decrease in the number of EB3-GFP comets in dendrites, whereas in axons the number of EB3-GFP comets was unchanged (data not shown). This effect occurred within 1-2 min after NMDA stimulation and persisted after the washout of the drug (Fig. 4D-F). In contrast, application of glycine/ $\mathrm{KCl}$ for $1 \mathrm{~min}$ to induce chemical LTP (Lu et al., 2001; Park et al., 2004) had no significant effect on EB3 comet dynamics (Fig. 4G,H).

Previous work has demonstrated that inhibition of microtubule dynamics redistributes the microtubule-binding protein EB3 from the growing microtubule plus-ends and decreases the number of EB3 comets in both fibroblasts and neuronal cells (Mimori-Kiyosue et al., 2000; Jaworski et al., 2009). To test whether the observed $\mathrm{EB} 3$ redistribution on NMDA receptor activation reflected a change in microtubule growth in dendrites, we expressed mCherry- $\alpha$-tubulin in neurons and directly analyzed microtubule dynamics by using TIRF microscopy. In control neurons, or neurons imaged before addition of NMDA, individual microtubules could be observed in dendrites, which alternated between periods of growth and shrinkage. NMDA receptor activation dramatically suppressed microtubule growth, resulting in either the shrinkage or stalling of microtubule ends (Fig. 5A-E). This rapid NMDA effect was specific for dynamic microtubules, since the overall microtubule organization was unaltered, as indicated by MAP2 and tubulin costaining (Figs. $1 A, B$, $3 A, B)$ (data not shown). Moreover, total EB3 and MAP2 levels were unchanged (Fig. 3E), and polymerized microtubule levels measured by tubulin preextraction (He et al., 2002) were not significantly affected (Fig. 6A,B). Similar to NMDA receptor activation, blocking microtubule dynamics directly by the addition of $200 \mathrm{~nm}$ nocodazole did not affect microtubule density (Fig. 6B) (Jaworski et al., 2009). These data indicate that chemical LTD suppresses microtubule growth, which results in a loss of EB3 comets and a more static microtubule network in dendrites.

Local NMDA stimulation affects microtubule dynamics

We next tested whether more local NMDA receptor activation also induced EB3 comet redistribution in dendrites. During timelapse imaging of EB3-GFP, hippocampal neurons were stimulated locally with a single $20 \mathrm{~s}$ puff of $100 \mu \mathrm{M}$ NMDA and $10 \mu \mathrm{M}$ glycine (Rose et al., 2009) delivered from a pipette placed near the dendrite. Consistent with bath application of NMDA, we observed that, within the stimulated portion of the dendrite, EB3- 
A
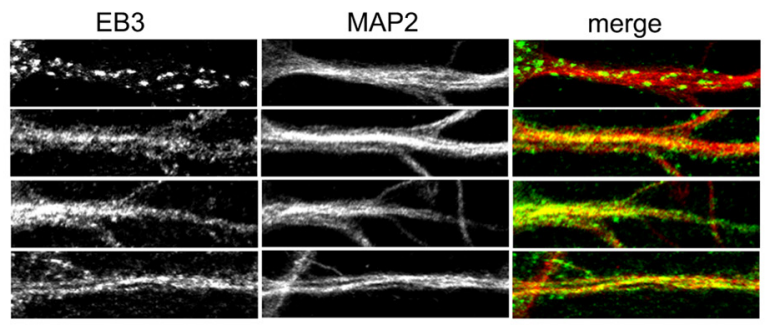

B
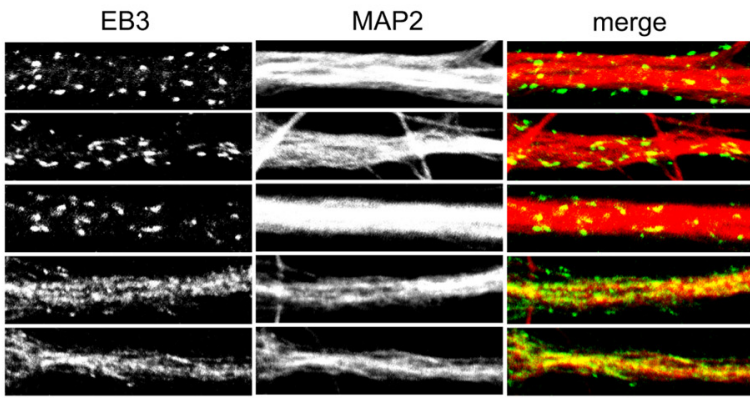

\section{C}
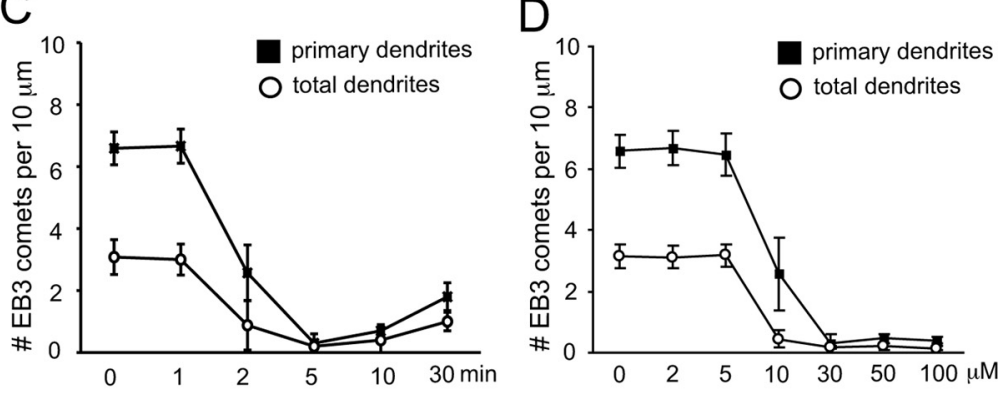

E

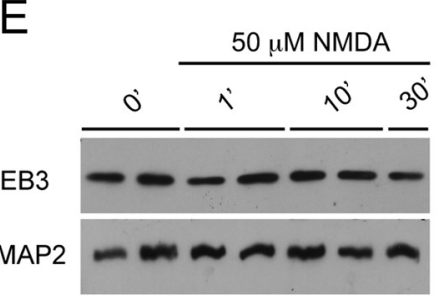

$\mathrm{F}$

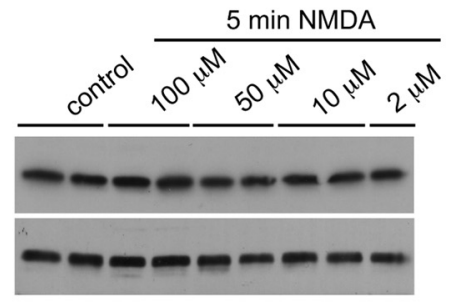

Figure 3. Time- and concentration-dependent effect of NMDA. $A, B$, High-magnification images of dendrites of hippocampal neurons (DIV17) untreated (control) or stimulated with $50 \mu$ M NMDA for various time intervals ( $\boldsymbol{A}$ ) or with various concentrations of NMDA for 5 min (B) and labeled with rabbit anti-EB3 antibody (green) and mouse anti-MAP2 (red). C, D, Quantification of the number of $E B 3$ comets per $10 \mu \mathrm{m}$ total or primary dendrite (mean \pm SEM) of hippocampal neurons stimulated with $50 \mu \mathrm{m}$ NMDA for various time intervals $(\boldsymbol{C})$ or with various concentrations of NMDA for $5 \mathrm{~min}(\boldsymbol{D}) . \boldsymbol{E}, \boldsymbol{F}$, Western blot analysis of extracts of hippocampal neurons either untreated or stimulated with $50 \mu \mathrm{M}$ NMDA for various time intervals $(\boldsymbol{E})$ or with various concentrations of NMDA for $5 \mathrm{~min}(\boldsymbol{F})$. Blots are probed for the indicated proteins. NMDA treatment did not affect total EB3 protein levels.

GFP comets disappeared on stimulation (Fig. $7 A, B$ ). The EB3 redistribution was confined to the stimulation site along the dendrite and was not observed in other dendrites from the same neurons or neighboring neurons. The effect was quickly reversible, since $\sim 1$ min after stimulation the displacement of EB3-GFP is back to control levels (Fig. 7C). These results show that local NMDA receptor stimulation can induce a transient effect on microtubule dynamics.

\section{EB3 localizes to MAP2-positive microtubule bundles on} NMDA receptor activation

To examine the persistence of EB3 redistribution after NMDA receptor activation, cultures were incubated with $50 \mu \mathrm{M}$ NMDA for 5 min, returned to their original medium, and subsequently fixed at different times points. Consistent with the above results, almost no control

1'NMDA

3' NMDA

10' NMDA

control

$2 \mu \mathrm{M} N M D A$

$10 \mu \mathrm{M} N M D A$

$30 \mu \mathrm{M}$ NMDA

$50 \mu \mathrm{M} N M D A$

endogenous EB3 comet-shaped staining was present in dendrites after $5 \mathrm{~min}$ of NMDA stimulation. Interestingly, $10 \mathrm{~min}$ after the washout, approximately one-third of the neurons instead showed an intense staining of endogenous EB3 along long and thick bundles in the dendritic shaft. In most neurons, the strongest effect was observed $25 \mathrm{~min}$ after washout (Fig. 8A-C). Quantification revealed that these EB3 accumulations are on average $5.8 \pm 0.7 \mu \mathrm{m}$ in length (EB3 comets in control cells are $0.81 \pm 0.4$ $\mu \mathrm{m})$, but several longer stretches were found, extending for $20-30 \mu \mathrm{m}$. NMDA receptors antagonists APV and MK-801 block this EB3 accumulation, as do exposure to BAPTA-AM and knockdown of NR2B (data not shown). Consistent with these immunohistochemical data, live-cell imaging of EB3-GFP also revealed the gradual recruitment to these filamentous structures starting $\sim 10$ min after NMDA treatment (Fig. $8 D, E$ ). These results indicate a second, more prolonged NMDA receptor-dependent effect on EB3 and the microtubule cytoskeleton.

Immunofluorescent analysis revealed that EB3 was not localized to the actin bundles that are often found in the dendritic shaft after glutamate treatment (Hering and Sheng, 2003) but was instead colocalized with a subset of microtubule structures, especially MAP2-positive microtubule bundles (Fig. 8G). EB3 did not show a preference for other microtubule subtypes, such as $\alpha$-, $\beta$ III-, and acetylated microtubules (data not shown). Moreover, in axons, the EB3 comet-like staining was still unaffected. No difference in total EB3 protein levels was found by Western blot analysis 25 min after washout (Fig. 8F). These results demonstrate that NMDA receptor activation affects EB3 localization in two phases; a rapid phase ( $>1 \mathrm{~min})$, during which EB3 comets are lost, and a slow phase $(>10$ min), during which EB3 emerges along MAP2 microtubule bundles.

Glutamate stimulation has been shown to decrease MAP2 phosphorylation (Halpain and Greengard, 1990; Montoro et al., 1993; Quinlan and Halpain, 1996). Within 15 min after NMDA receptor activation, a 95\% decrease in MAP2 phosphorylation was observed (Quinlan and Halpain, 1996). Because these MAP2-dephosporylation events occur at a similar timescale as the EB3 recruitment along MAP2-positive microtubules (Fig. 8G), we tested the correlation between the EB3 redistribution and phosphorylation state of MAP2 by using Ser-136 phosphoantibodies (AP-18) (Berling et al., 1994; Kalcheva et al., 1994). Indeed, NMDA treatment decreased overall MAP2 phosphorylation (Fig. $8 F$ ) and phospho-MAP2Ser-136 was mostly absent from dendrites with intense filamentous staining of EB3 (Fig. 8H). The positive correlation between MAP2-dephosphorylation on Ser-136 and EB3 accumulation 


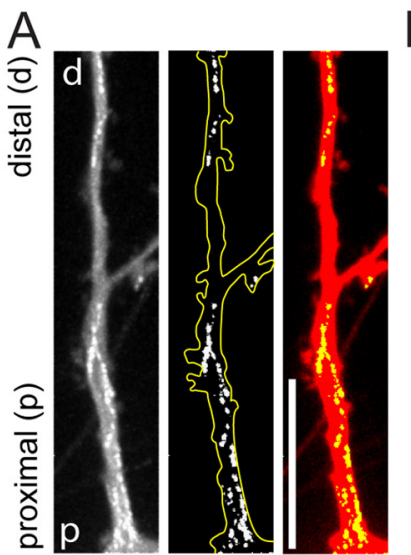

B
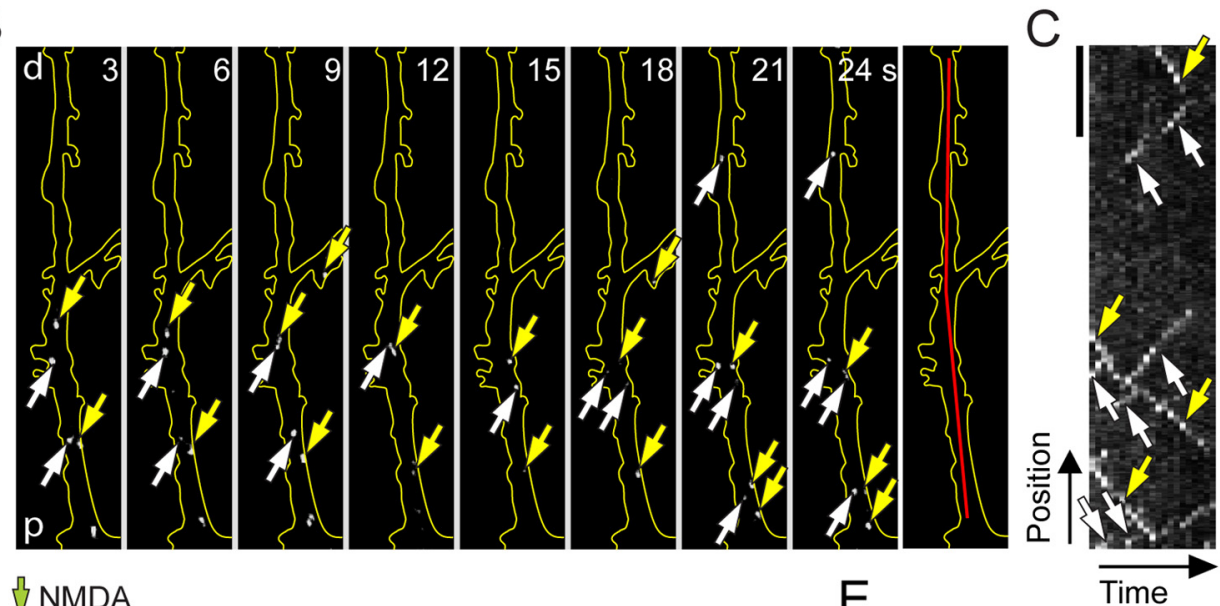

$\mathrm{D}$

ת NMDA

$\mathrm{E}$
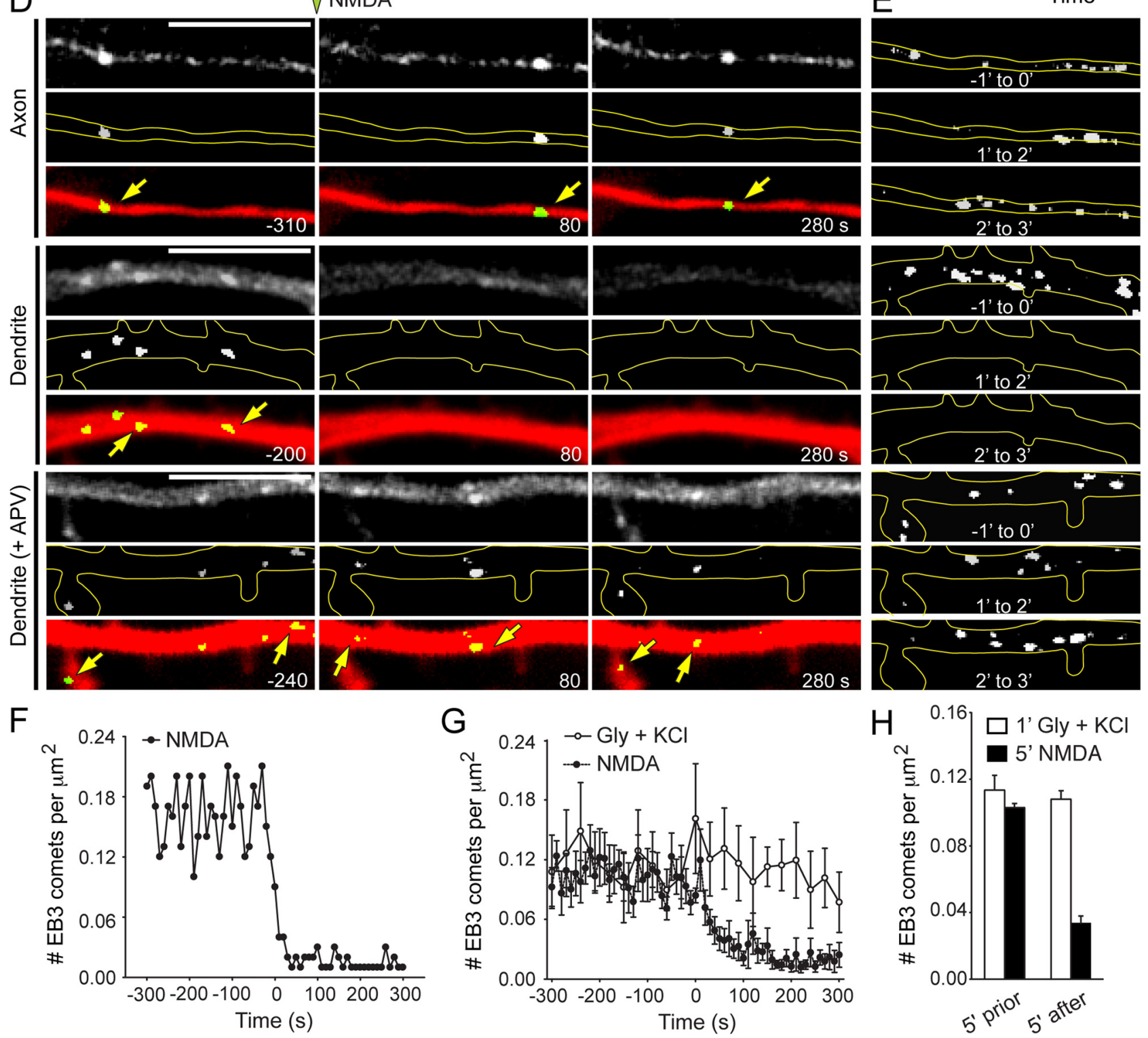

Figure 4. NMDA receptor activation suppresses EB3 plus-end tracking. $A$, Dendritic region of a hippocampal neuron expressing EB3-GFP, shown as maximum intensity projection of a low-passfiltered sequence of 21 frames acquired using spinning disk confocal microscopy (left). The middle image shows the maximum projection with the average projection subtracted. The right image shows overlay of middle image and average projection. Scale bar, $10 \mu \mathrm{m}$. " $\mathrm{p}$ " and " $\mathrm{d}$ " mark proximal and distal ends, respectively. $\boldsymbol{B}$, Stills from the time-lapse recording corresponding with $\boldsymbol{A}$. The white and yellow arrows indicate EB3 comets moving toward the distal or proximal end of the dendrite, respectively. The time-lapse recording was low-pass filtered and individual frames were average subtracted. The final image indicates region used for kymography in C. C, Kymograph corresponding to the recording shown in $\boldsymbol{B}$. The white and yellow arrows indicate EB3 comets moving toward the distal or proximal end of the dendrite, respectively. Scale bar, $5 \mu \mathrm{m}$. Total time, $1 \mathrm{~min}$. D, Spinning disk confocal images of axon and dendritic segments of hippocampal neurons treated with $50 \mu \mathrm{M}$ NMDA for $5 \mathrm{~min}$ (axon and dendrite) or $50 \mu \mathrm{m} \mathrm{NMDA} \mathrm{for} 5 \mathrm{~min}$ in the presence of $200 \mu \mathrm{m} \mathrm{APV} \mathrm{(dendrite} \mathrm{plus} \mathrm{APV).} \mathrm{At} \mathrm{each} \mathrm{time} \mathrm{point,} \mathrm{(Figure} \mathrm{legend} \mathrm{continues.)}$ 

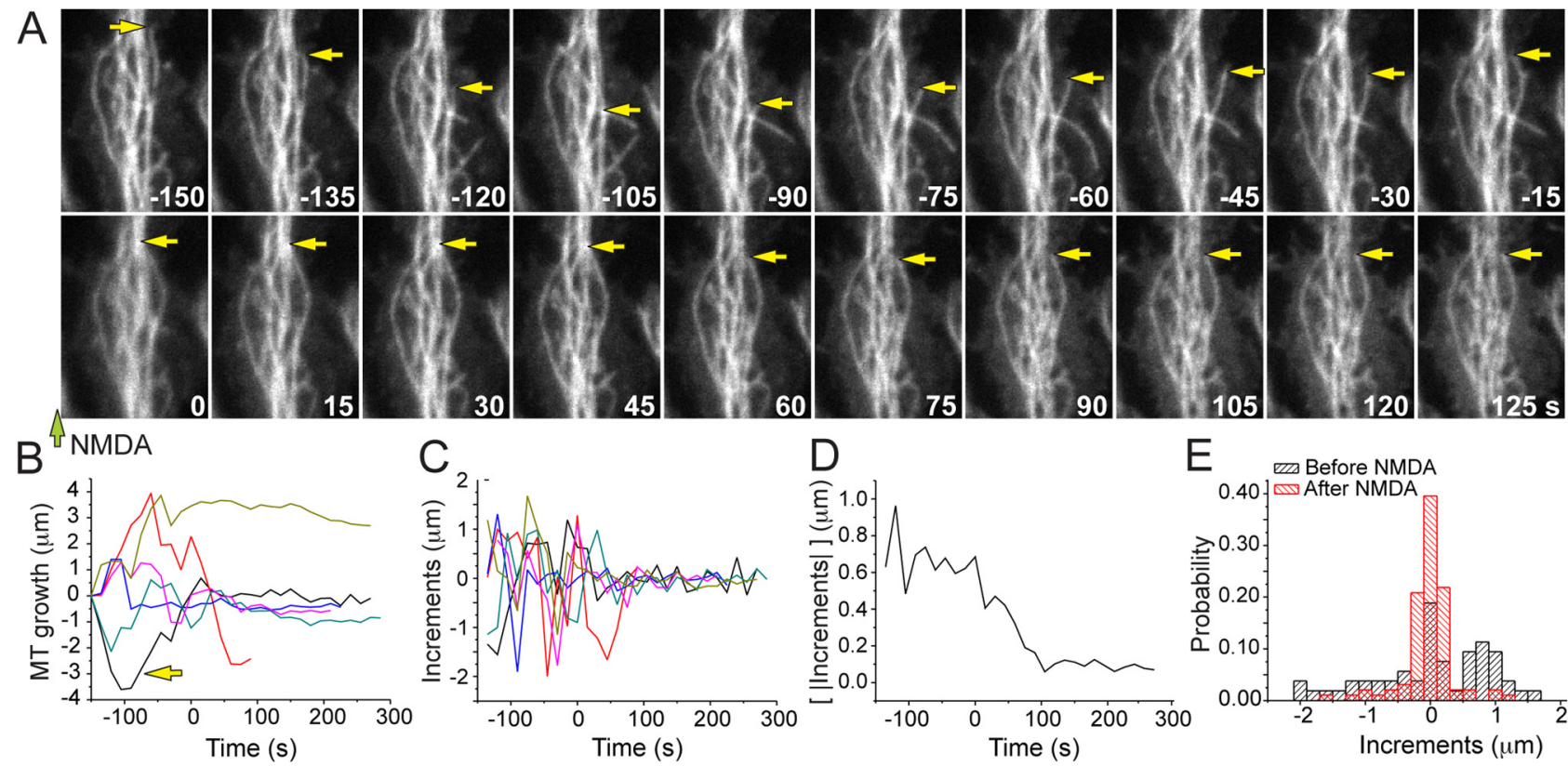

Figure 5. NMDA stimulation suppresses microtubule growth. $A$, Stills from a TIRFM time-lapse recording of dendritic microtubules labeled using mCherry-tubulin, showing microtubule dynamics before and after addition of $100 \mu \mathrm{m} \mathrm{NMDA}$ treatment at $t=0$. The arrows highlight example microtubule whose dynamics are suppressed on NMDA addition. Also see video 3 (see Notes). $\boldsymbol{B}$, Plot of microtubule tip position relative to $t=-150 \mathrm{~s}$ for six traceable microtubules. C, Plot of consecutive length increments for the traces shown in $\boldsymbol{B}$. Negative values indicate shrinkage. $\boldsymbol{D}$, Average of absolute increment values for the traces shown in B. E. Histogram of all increments before (black) and after (red) treatment with NMDA.
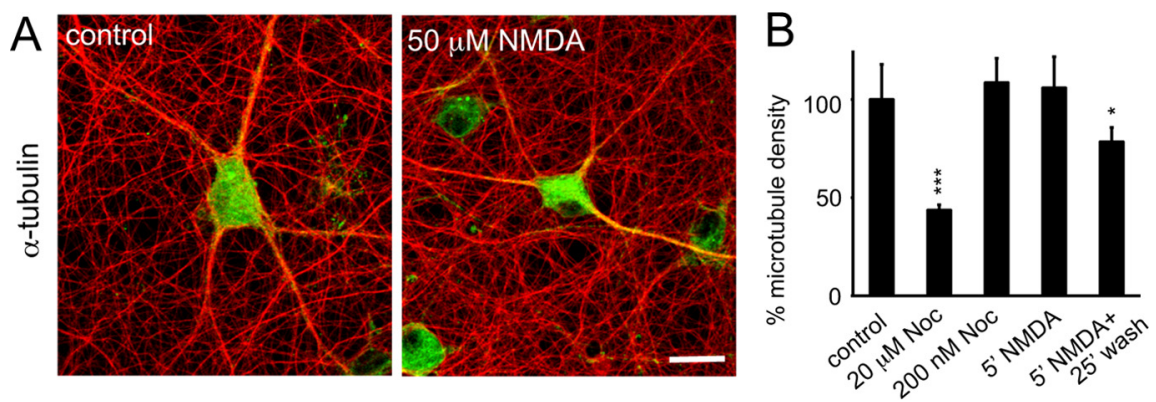

Figure 6. NMDA-dependent effect on microtubule density. $\boldsymbol{A}$, Measurement of polymerized microtubule levels by tubulin preextraction method. Hippocampal neurons were treated with vehicle (control) or $50 \mu \mathrm{M} \mathrm{NMDA}$, fixed and extracted at the same time to eliminate free tubulin monomers, and double-labeled with rabbit anti-EB3 antibody (green) and mouse anti- $\alpha$-tubulin antibody (red). Polymerized microtubules are present in dendrites and axons in untreated neurons. Treatment of hippocampal neurons with $50 \mu \mathrm{m}$ NMDA for 5 min has no effect on microtubule density. Scale bar, $20 \mu \mathrm{m}$. B, Quantification of relative microtubule density (compared with control neurons) in hippocampal neurons under indicated conditions. Error bars indicate SEM. ${ }^{*} p<0.05 ; * * * 00.0005$.

was maximal at 25 min after NMDA treatment (Fig. $8 H$ ). Together with the live-imaging data, these results suggest that NMDAmediated dephosphorylation of MAP2 gradually recruit EB3 along dendritic microtubules.

(Figure legend continued.) the top, middle, and bottom panels show low-pass-filtered image, low-pass-filtered data with average subtracted, and merge of middle panel (green) and average image (red), respectively. Scale bar, $5 \mu \mathrm{m}$. Also see videos 1 and 2 (see Notes). $\boldsymbol{E}$, Maximum projection of time-lapse-filtered stacks shown in $\boldsymbol{D}$ for the indicated time intervals. $\boldsymbol{F}$, Time trace of the number of $\mathrm{EB} 3$ comets per square micrometer from a single time-lapse recording. NMDA $(50 \mu \mathrm{m})$ is added at $0 \mathrm{~s}$. G, Average time traces of the number of EB3 comets per square micrometer before and after application (at $0 \mathrm{~s}$ ) of either $200 \mu \mathrm{m}$ glycine and $50 \mathrm{~mm} \mathrm{KCl}$ for $1 \mathrm{~min}$ (open circles; $N=4$ neurons) or $50 \mu \mathrm{m} \mathrm{NMDA}$ (closed circles; $N=8$ neurons). Error bars denote SEM. $\boldsymbol{H}$, Average number of EB3 comets per square micrometer during the 5 min before and after chemical LTP (glycine plus KCI) or LTD (NMDA). Error bars are SEM.

\section{EB3 binds directly to MAP2}

To further validate the association between MAP2 and EB3, we performed GST pull-down experiments using GST-EB3 and lysates of HEK293 cells expressing GFP-MAP2c. These experiments revealed a specific interaction between MAP2 and EB3 (Fig. 9A-C), as GFP-MAP2c strongly associated with the GST-EB3 but not with GST alone. Mass spectrometry analysis of GST-EB3 pull-down experiments from rat brain extracts confirmed the interaction with endogenous MAP2, along with other known EB binding proteins (Table 1). The interaction between EB3 and MAP2 is direct because a purified MAP2 fraction from bovine brain interacts with GST-EB3 (Fig. 9G). Interestingly, from the purified MAP2 fraction, MAP2c was most efficiently pulled down with GSTEB3, rather than the longer MAP2 isoforms (Fig. 9G). Furthermore, treating GFP-MAP2c-expressing HEK293 cells with the general ATP-competitive protein kinases inhibitor staurosporine resulted in increased binding of MAP2 to EB3 in pull-down experiments (Fig. 9A-C), consistent with our observation that EB3 recruitment to MAP2 correlates with MAP2 dephosphorylation (Fig. $8 F, H$ ). These data indicate that EB3 has a higher affinity for dephosphorylated MAP2.

GFP-MAP2c expression in heterologous cells causes a rearrangement of microtubules into bundles (Takemura et al., 1992; Kaech et al., 1996; Dehmelt et al., 2006). We next tested whether MAP2 in COS-7 cells is able to redistribute and recruit endogenous EB3 along these microtubule bundles. In control cells, EB3 was present as comet-shaped structures that labeled growing microtubule plus-ends (Fig. 9D). However, in GFP-MAP2cexpressing cells, all endogenous EB3 is concentrated along the 

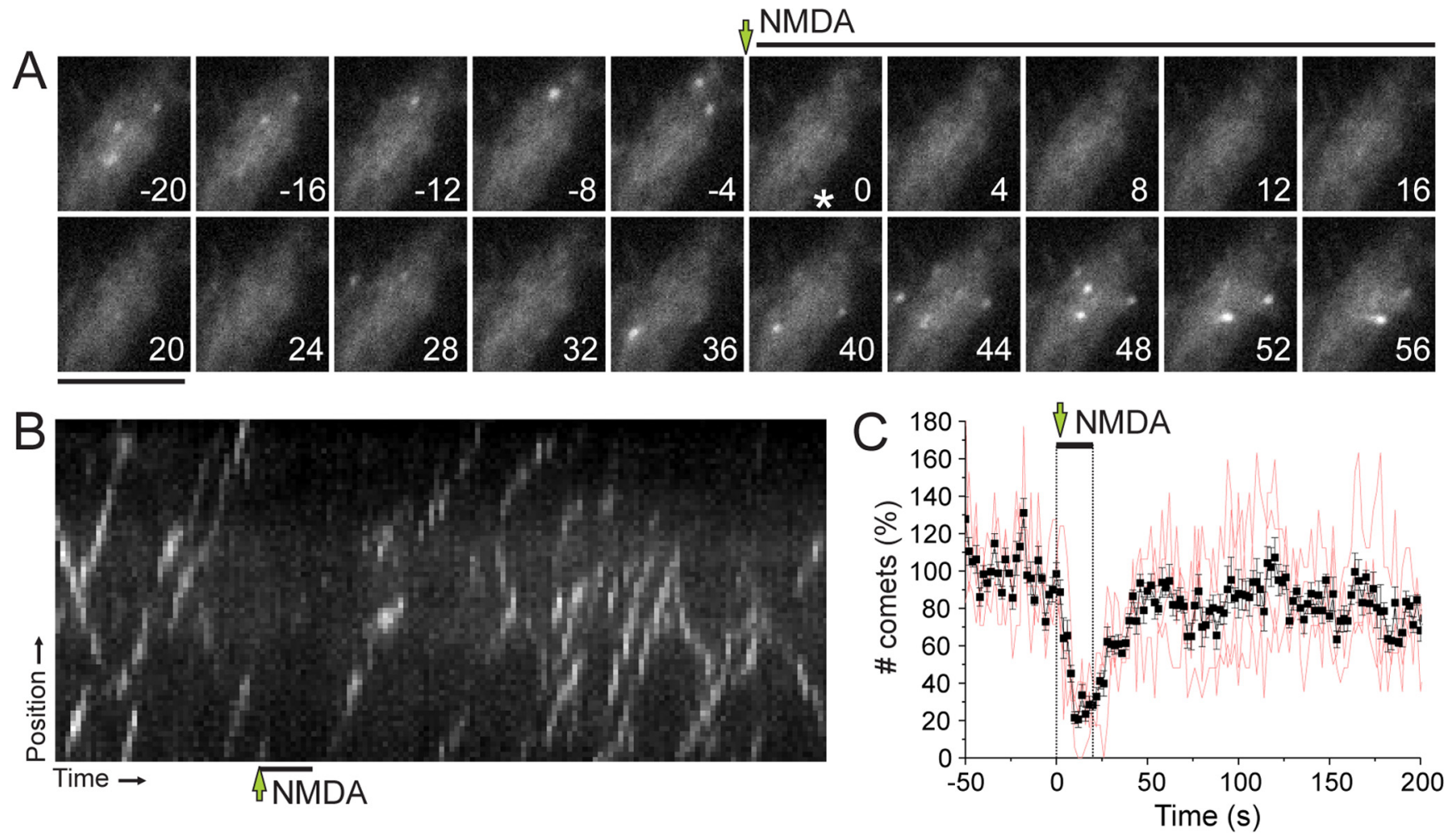

Figure 7. Local NMDA stimulation transiently affects microtubule dynamics. A, Stills from a TIRFM time-lapse recording of EB3-GFP at growing microtubule plus-ends, showing microtubule dynamics before and after a $20 \mathrm{~s}$ puff of $100 \mu \mathrm{m} \mathrm{NMDA}$ and $10 \mu \mathrm{m}$ glycine at $t=0 . \boldsymbol{B}$, Kymograph of the recording in $\boldsymbol{A}$ showing EB3-GFP comet dynamics before and after chemical stimulation. $\boldsymbol{C}$, Individual (red) and average (black) time traces of the relative number of comets in a $10 \mu \mathrm{m}$ radius circle around the pipette outlet, measured in four different neurons. A $20 \mathrm{~s}$ puff of $100 \mu \mathrm{m}$ NMDA and $10 \mu \mathrm{m}$ glycine was applied at $t=0$. Error bar represents SEM.

MAP2-induced microtubule bundles (Fig. 9D), confirming the interaction between MAP2c and EB3. Endogenous EB3 was not relocalized to GFP-KIFC2-induced microtubule bundles (data not shown), indicating that EB3 specifically binds to MAP2 microtubules. MAP2 is a multidomain protein, with an N-terminal projection domain (Pro) and a C-terminal microtubule binding (MT) sites (Dehmelt and Halpain, 2005) (Fig. 9I), and by expressing GFP-fused deletion mutants of MAP2 in COS-7 cells, we mapped the EB3 binding region within the C-terminal microtubule-binding domain of MAP2 (Fig. 9D). This was confirmed by GST pull-down assays using GST-EB3 and extracts from HEK293 cells expressing GFP-MAP2c-MT (Fig. 9E).

EB proteins contain a $\mathrm{N}$-terminal microtubule-binding calponin homology domain, responsible for the recognition of the polymerizing microtubule ends, and the C-terminal domain consisting of a dimeric coiled coil, which ends in a four-helix bundle and a C-terminal acidic tail, responsible for binding to partners (Akhmanova and Steinmetz, 2008; Hoogenraad and Akhmanova, 2010) (Fig. 9I). Since MAP2c-MT is rich in basic, serine, and proline residues (SxI/LP), we next investigated whether the acidic tail of EB3 is important for interaction between EB3 and MAP2. An EB3 mutant that lacks the acidic tail (GST-EB3 $\triangle A$ Ac) does not bring down GFP-MAP2 in GST-pull down assays indicating that the acidic C-terminal tail of EB3 is important for the interaction with MAP2 (Fig. 9F). We also tested whether the C-terminal tail of EB3 (EB3-C), which lacks the N-terminal microtubule-binding domain, accumulates along MAP2-associated microtubule bundles after NMDA receptor activation. In nonstimulated neurons, GFP-EB3-C is diffusely present through the cytoplasm and does not interact with microtubules, as expected (Komarova et al., 2005), whereas $25 \mathrm{~min}$ after NMDA treatment GFP-EB3-C accumulates along MAP2 positive microtubules in the dendritic shaft (Fig. $9 H$ ). Thus, although the EB3-C constructs lacks the classic microtubule binding domain at the $\mathrm{N}$ terminus, the $\mathrm{C}$-terminal region can associate with microtubules via MAP2. Together, these data demonstrate that the $\mathrm{C}$-terminal domain of EB3 is both necessary and sufficient for MAP2 binding.

Because many other MAPs are present in dendrites of hippocampal neurons, we next used MAP2 knockdown experiment to examine whether MAP2 is necessary for EB3 recruitment after NMDA receptor activation. We found that NMDA treatment did not induce EB3 recruitment in cells transfected with MAP2shRNA (Fig. 10). Together, these results demonstrate MAP2 directly binds to EB3, and this interaction is both necessary and sufficient for the accumulation of EB3 along microtubules after NMDA treatment.

\section{EB3 overexpresssion protects spines against LTD-induced spine shrinkage}

Whereas most dendritic EB3-GFP comets are found in the dendritic shaft, EB3-GFP comets can also enter dendritic spines and induce spine growth (Jaworski et al., 2009) (Fig. 11A-F). In agreement with our previous findings (Jaworski et al., 2009), we observed an average of $0.07 \pm 0.03 \mathrm{~EB} 3$ comet entries per spine per frame in control neurons (Fig. $11 G$ ). Since NMDA receptor activation attenuates microtubule growth, we tested whether microtubule entry in spines is also affected. Indeed, bath application of NMDA has a robust effect on persistent microtubule growth; most dendritic microtubules stopped growing and EB3-GFP entries into spines were almost completely abolished during the 5 min after NMDA addition (Fig. $11 G-I$ ). 
A

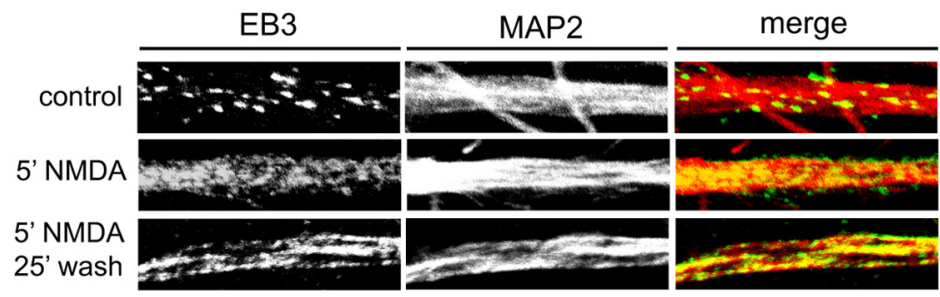

D
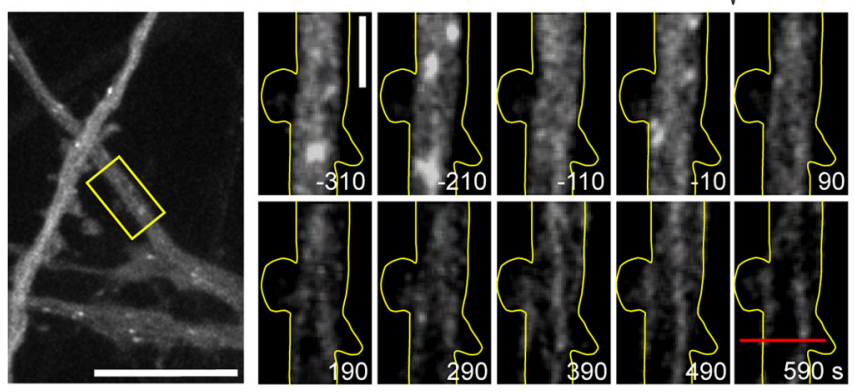

B
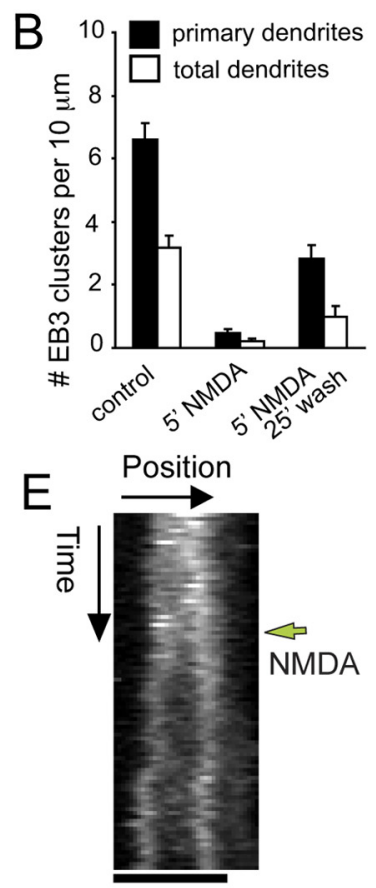
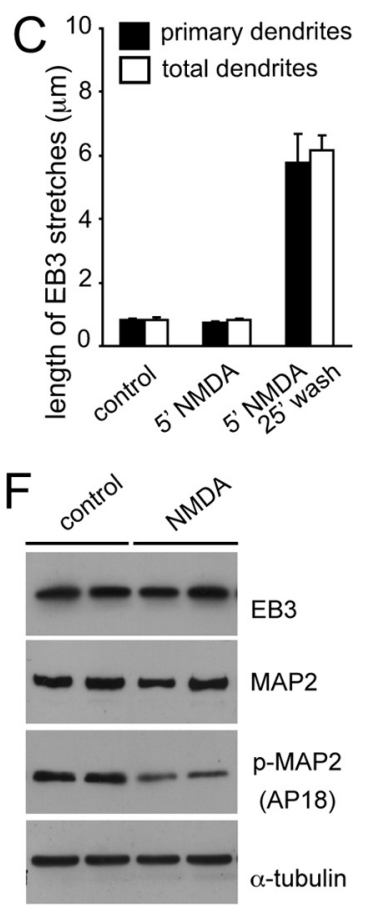

$\mathrm{G}$

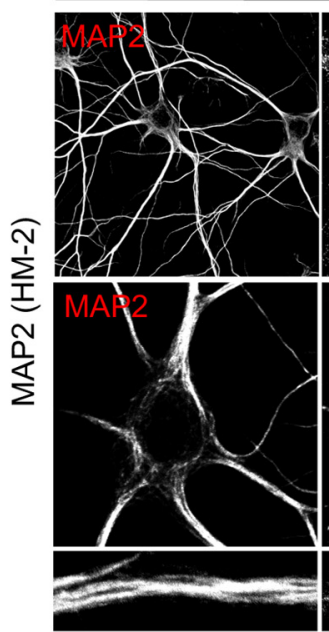

$\mathrm{H}$

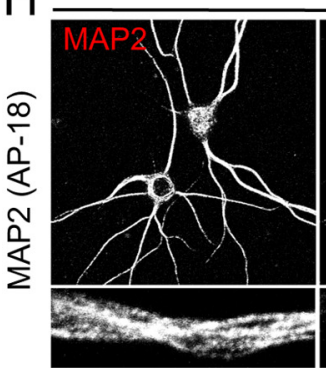

Control

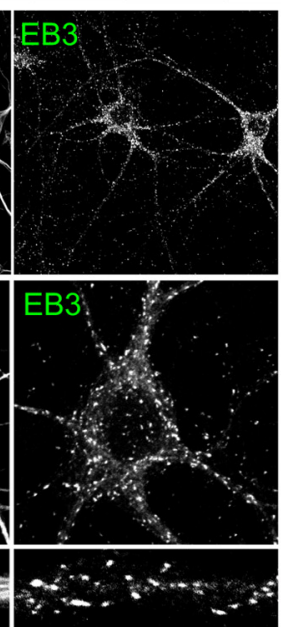

Control

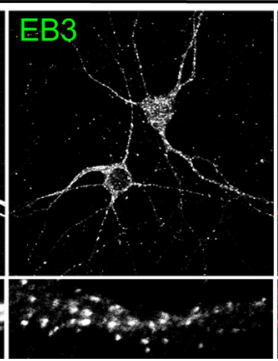

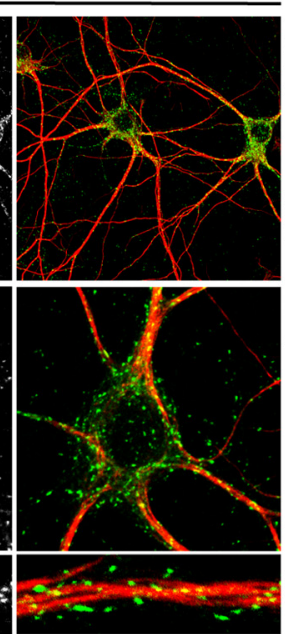

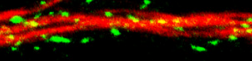

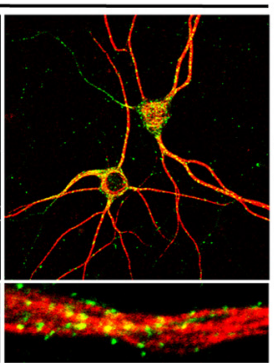

5' NMDA + 25' wash

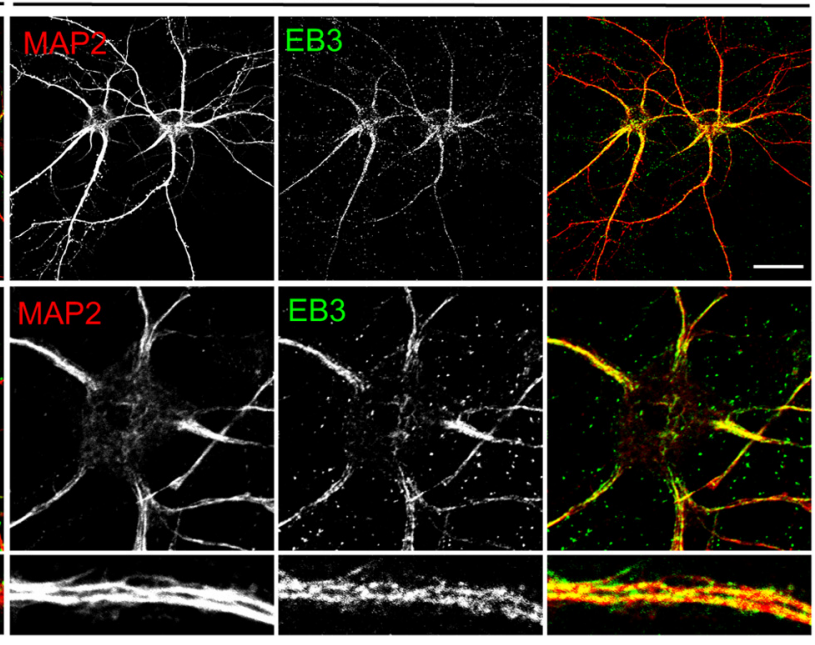

5' NMDA + 25' wash
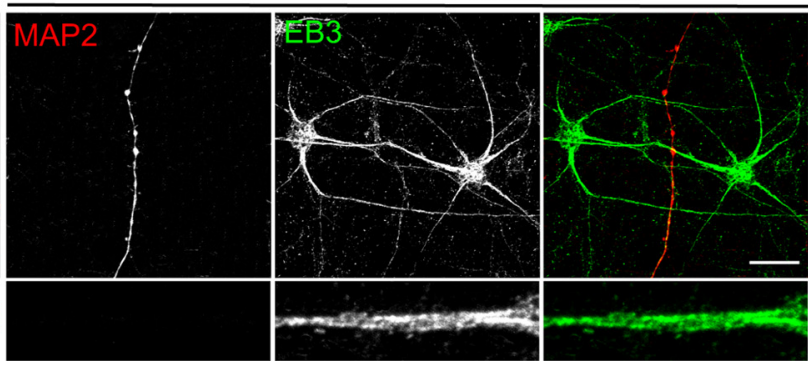

Figure 8. NMDA induces EB3 localization along MAP2 microtubules. A, High-magnification images of dendrites of hippocampal neurons (DIV17) untreated (control) or treated with $50 \mu \mathrm{MNMDA}$ for 5 min with or without 25 min washout and double-labeled with rabbit anti-EB3 antibody (green) and mouse anti-MAP2 antibody (red). Only the merge is shown in color. B, Quantification of the number of EB3 comets per $10 \mu \mathrm{m}$ total or primary dendrites (mean \pm SEM) of hippocampal neurons stimulated as indicated in $A$. C, Quantification of the length of the EB3 stretches (in micrometers) in total or primary dendrites (mean \pm SEM) of hippocampal neurons stimulated as indicated in $A$. $\boldsymbol{D}$, Low-pass-filtered frame of a time-lapse recording of hippocampal neurons expressing EB3-GFP acquired with a spinning disk confocal microscope. The yellow box marks region used for zoomed still. Before addition of NMDA (marked by green arrow), EB3 comets are visible, whereas several minutes after NMDA treatment EB3 stretches appear. Scale bars: first image, $10 \mu \mathrm{m} ; z 00 \mathrm{~ms}, 2 \mu \mathrm{m}$. Also see video 4 (see Notes). E, Kymograph of the red region indicated in D. Stable, bright EB3-positive bundles appear after NMDA application (green arrow). Scale bar, $2 \mu \mathrm{m}$. Total time, 16:30 (min:sec). $\boldsymbol{F}$, Western blot analysis of extracts of hippocampal neurons either untreated or treated for 5 min with $50 \mu \mathrm{m}$ NMDA. Blots are probed for the indicated proteins. Quantification of the signal intensities (mean \pm SD) of total MAP2 (HM-2 antibody) and phosphorylated MAP2 bands (AP-2 antibody) revealed that NMDA decreases MAP2 phosphorylation. HM-2 antibody (control, $71.97 \pm 5.76 ; \mathrm{NMDA}, 61.20 \pm 12.58 ; p=0.424$ ) and AP-2 antibody (control,61.36 $\pm 1.44 ; \mathrm{NMDA}, 31.14 \pm 3.12 ; p=0.021$ ). G, H, Representativeimages of rathippocampal neurons (DIV17) untreated (left) or treated with $50 \mu \mathrm{m}$ glutamate for $5 \mathrm{~min}$ with $25 \mathrm{~min}$ washout (right) and double-labeled with rabbit anti-EB3 antibody (green) and mouse anti-MAP2 antibody (red) (G) or mouse anti-MAP2 Ser-136 phosphoantibody (AP-18; red) (H). Only the merge is shown in color. The cell body and dendrites (bottom panels) are enlarged to show the localization of EB3 before and after NMDA stimulation. Scale bar, $20 \mu \mathrm{m}$. 
A

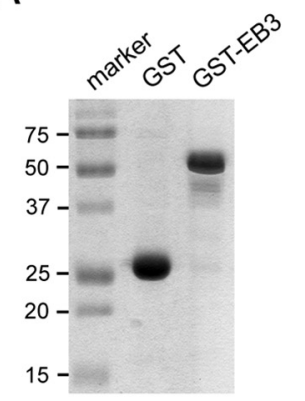

B
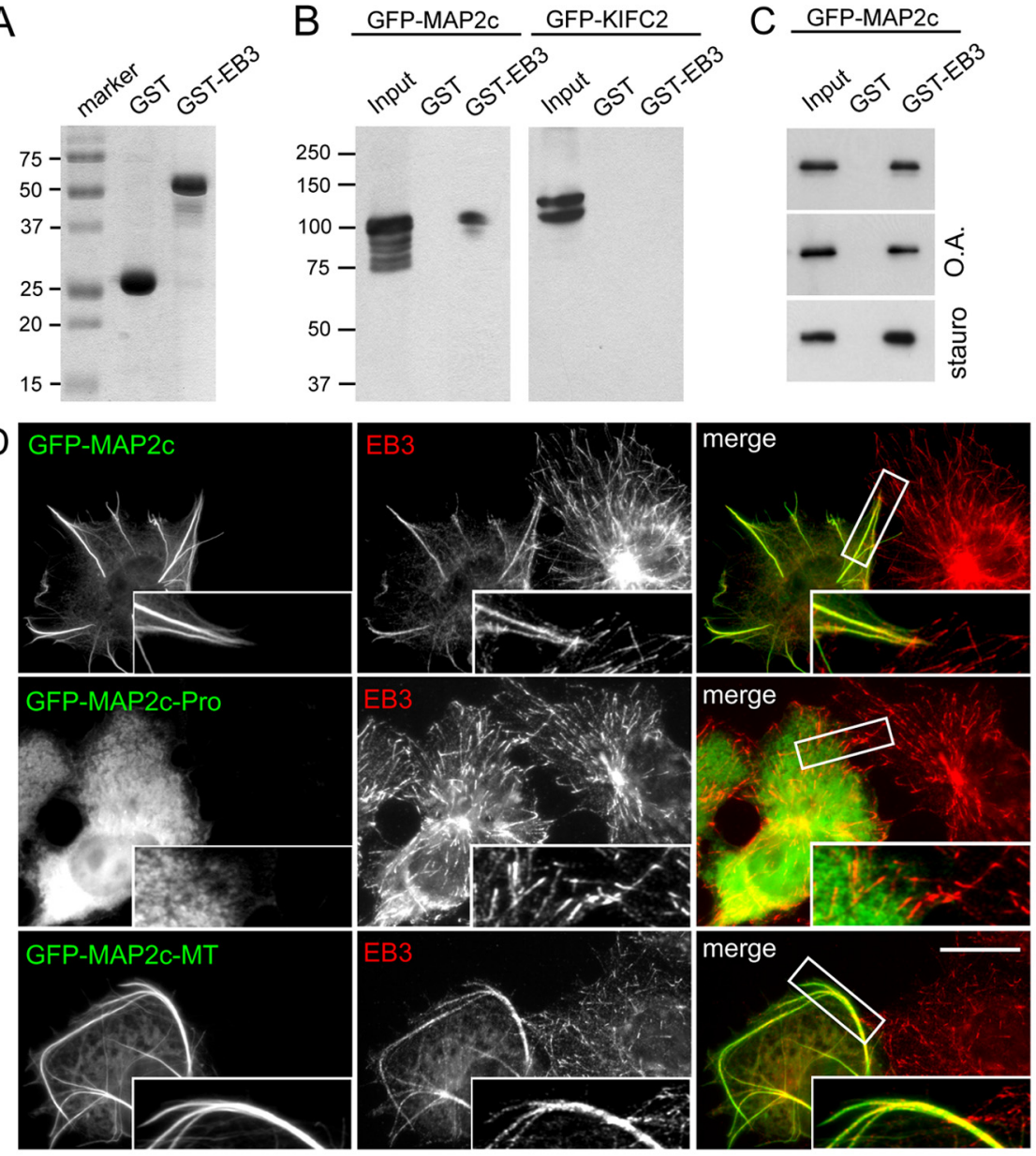

E GFP-MAP2C-Pro GFP-MAP2C-MT F GFP-MAP2C
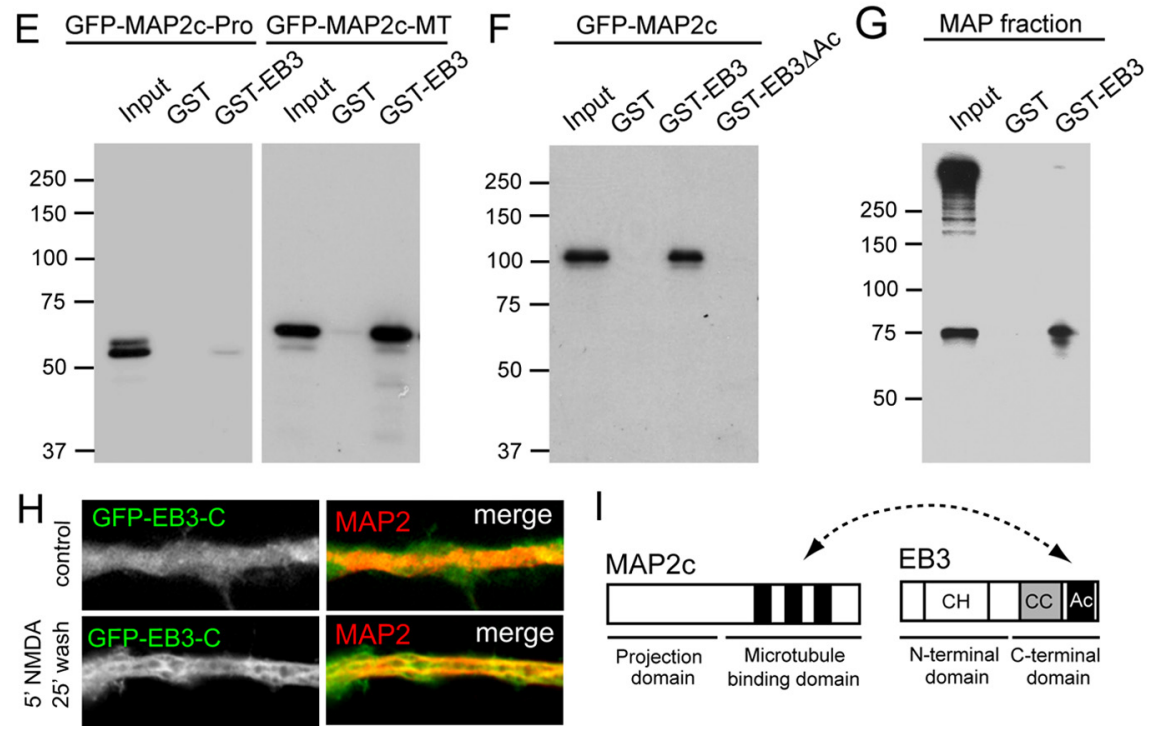

Figure 9. EB3 binds to MAP2. A, Coomassie-stained gel of GST and GST-EB3 fusion proteins. $B$, GST pull-down assays with the GST alone and GST-EB3 fusion proteins and extracts of HEK293 cells overexpressing GFP-MAP2c and GFP-KIFC2. GFP fusions were detected by Western blotting with antibodies against GFP. C, GST pull-down assays with the GST alone and GST-EB3 fusion proteins and extracts of HEK293 cells overexpressing GFP-MAP2c and untreated or treated with okadaic acid (0.A.) (0.5 $\mu \mathrm{m}$ for $60 \mathrm{~min}$ ) or staurosporine (stauro) (1.0 $\mu \mathrm{m}$ for $60 \mathrm{~min})$. Quantification of the ratio of signal intensities (mean \pm SD) of GFP-MAP2 input and GST-EB3 pull down revealed that staurosporine treatment increased binding of MAP2. Control ratio is $0.74 \pm 0.15,0 . \mathrm{A}$. ratio is $0.65 \pm 0.12(p=0.243)$, and stauro ratio is $1.27 \pm 0.18(p=0.016)$. D, COS-7 cells transfected with GFP-MAP2c, GFP-MAP2cpro, or GFP-MAPc-MT (green) and stained for endogenous EB3 (red). The insets show enlargements of the boxed area. Scale bar, 10 $\mu \mathrm{m} . \mathbf{E}$, GST pull-down assays with the GST alone and GST-EB3 fusion proteins and extracts of HEK293 cells overexpressing GFP-MAP2C-Pro and GFP-MAP2C-MT. GFP fusions were detected by Western blotting with antibodies against GFP. F, GST pulldown assays with the GST alone, GST-EB3, and GST-EB3 $\triangle$ Ac fusion proteins and extracts of HEK293 cells overexpressing GFP-MAP2C.
It has been shown that neurons exposed to a chemical LTD protocol change spine morphology (Halpain et al., 1998; Horne and Dell'Acqua, 2007). Indeed, bath application of $50 \mu \mathrm{M}$ NMDA significantly decreased the number of spines, without affecting protrusion density (Fig. $11 J-L)$. Intriguingly, EB3 knockdown (Fig. $11 \mathrm{~J}-L$ ) has similar effects on spine morphology as NMDA treatment, and we therefore investigated whether these effects are mutually occlusive. However, NMDA receptor activation did not further reduce the number of spines in neurons transfected with shRNA-EB3. To further establish the role of microtubules in LTDinduced spine morphology, we increased the number of microtubules in dendritic spines by overexpression of EB3-GFP (Jaworski et al., 2009). Our previous results have shown that overexpression of EB3GFP transiently stabilizes microtubules in dendritic spines and increases the number of mushroom spines (Jaworski et al., 2009). In contrast to control neurons, where NMDA receptor activation reduced the number of spines, NMDA treatment hardly affected spine numbers in neurons expressing EB3-GFP (Fig. $11 \mathrm{~J}-\mathrm{L}$ ), indicating that targeting of EB3-labeled microtubules to spines blocks LTD-induced spine remodeling. No protective effect could be seen with expression of other microtubule-binding proteins, such as CLIP-115 and GFPKIFC2 (data not shown). Together, these experiments demonstrate an intricate involvement of EB3-labeled microtubules in regulating spine morphology during LTD.

\section{Discussion}

The microtubule cytoskeleton plays a fundamental role in maintaining neuronal morphology and function and also contributes to the organization of dendritic spines and excitatory synapses (Hoogenraad and Bradke, 2009). We have shown

$\leftarrow$

GFP fusions were detected by Western blotting with antibodies against GFP. G, GST pull-down assays with the GST alone and GST-EB3 fusion proteins and purified microtubuleassociated protein (MAP) fraction from bovine brain. $\boldsymbol{H}$, Highmagnification images of dendrites of hippocampal neurons (DIV17) transfected with GFP-EB3-C untreated (control) or stimulated 5' (5 min) with $50 \mu \mathrm{m}$ NMDA followed by $25 \mathrm{~min}$ washout and labeled with mouse anti-MAP2 (red). I, Schematic representation of $M A P 2 c$ and $E B 3$ protein structure and deletion mutants used in this study. The arrow indicates the domains important for the interaction between EB3 and MAP2. CH, Calponin homology domain; $\mathrm{CC}$, coiled coil; AC, acidic tail. 
Table 1. Binding partners of GST-EB3 in rat brain extracts identified by mass spectrometry

\begin{tabular}{lllllr}
\hline $\begin{array}{l}\text { Identified } \\
\text { protein }\end{array}$ & $\begin{array}{l}\text { Molecular } \\
\text { weight }(\mathrm{Da})\end{array}$ & \% Cover & $\begin{array}{l}\text { Peptides } \\
\text { unique }\end{array}$ & $\begin{array}{l}\text { Peptides } \\
\text { total }\end{array}$ & \multicolumn{1}{c}{$\begin{array}{l}\text { NCBI GI } \\
\text { number }\end{array}$} \\
\hline CLIP-115 & 116,260 & 53.9 & 45 & 155 & 149063106 \\
MAP2 & 202,744 & 38.3 & 49 & 177 & 547890 \\
CLIP-170 & 148,800 & 29.5 & 31 & 57 & 8247352 \\
CLASP2 & 141,463 & 44.3 & 44 & 172 & 16758540 \\
p140Cap & 138,559 & 3.2 & 4 & 4 & 9507127 \\
\hline
\end{tabular}

The table shows proteins identified with a significant Mascot score in GST-EB3 pull downs from rat brain extracts. The list is corrected for background proteins that were identified in a control GST pull down. For each identified protein the list is filtered for duplicates and shows only the hits with most identified peptides. Abbreviations used in the table to indicate the identified proteins are as follows: CLIP-115, cytoplasmic linker protein of $115 \mathrm{kDa}$ (also known as CLIP2, CYLN2, WSCR4, WBSCR4); MAP2, microtubule-associated protein 2; CLASP2, cytoplasmic linkerassociating protein 2 [also known as multiple asters (Mast)-like homolog 2]; CLIP-170, cytoplasmic linker protein of $170 \mathrm{kDa}$ (also known as CLIP1, Restin); p140Cap, p130Cas-associated protein of $140 \mathrm{kDa}$ [also known as SNIP (SNAP-25-interacting protein)].

here that transient NMDA receptor activation using a chemical LTD protocol suppresses dendritic microtubule dynamics and microtubule entry into dendritic spines. Our data suggest a model in which activity-dependent modulation of the neuronal microtubule cytoskeleton contributes to the local structural plasticity that facilitates neuronal circuitry remodeling.

\section{NMDA receptor activation suppresses microtubule growth in dendrites}

One form of long-lasting synaptic modulation in the hippocampus is LTD, which is triggered by the synaptic activation of NMDA receptors (Bear and Abraham, 1996; Collingridge et al., 2004). Calcium influx through the NMDA receptor activates a number of signaling pathways that have been implicated in the regulation of AMPA receptor trafficking, translation of local $\mathrm{mR}$ NAs, and the induction of gene expression (Malinow and Malenka, 2002; Sheng and Kim, 2002; Kennedy et al., 2005; Shepherd and Huganir, 2007; Greer and Greenberg, 2008). In addition, NMDA receptor activation also modulates the function of several cytoskeletal proteins and influences neuronal morphology (Halpain and Greengard, 1990; Wong and Ghosh, 2002; Hotulainen and Hoogenraad, 2010). Consistently, our work now demonstrates that transient NMDA receptor activation affects microtubule organization in dendrites in two phases; a fast phase $(>1 \mathrm{~min})$ that leads to reduced microtubule growth and the loss of EB3 comets at the microtubule plus-end and a slow phase ( $>10 \mathrm{~min}$ ) during which EB3 binds along MAP2-positive microtubule bundles.

Previous work has revealed a close relationship between glutamate receptor activation and the modulation of MAP2 phosphorylation (Halpain and Greengard, 1990; Montoro et al., 1993; Quinlan and Halpain, 1996). NMDA-induced MAP2 dephosphorylation occurs gradually and takes several minutes to complete (Halpain and Greengard, 1990; Quinlan and Halpain, 1996), suggesting that the initial effects on EB3 and microtubule dynamics are independent of MAP2 modifications. Indeed, neurons lacking MAP2 show normal EB3 distributions and NMDA stimulation results in loss of EB3 comets similar to control neurons (Fig. 10), indicating that MAP2 is not involved in the initial regulation of EB3 localization and suppression of microtubule growth. Instead, the initial disappearance of EB3 comets from microtubule plus-ends is most likely a consequence of the stalling of microtubule growth.

How does NMDA receptor activation suppress microtubule growth? One possibility is that the initial phase of suppressed microtubule dynamics is a direct effect of the increased calcium concentration in the neurons. In vitro studies on MT assembly using purified tubulin have shown that calcium in the millimolar range directly affects microtubule polymerization (Olmsted and Borisy, 1975; Strömberg and Wallin, 1994). Studies in detergentextracted cells showed that microtubules polymerize at low calcium concentrations, whereas increasing calcium concentrations to the micromolar range directly induced microtubule disassembly (Fuller and Brinkley, 1976; Schliwa, 1976). These effects have been hypothesized to be mediated by calcium-dependent regulators of microtubule assembly, such as the abundant neuronal protein calmodulin (Marcum et al., 1978; Schliwa et al., 1981; Lee and Wolff, 1982; Deery et al., 1984). A recent report furthermore suggests that posttranslational modifications that are associated with microtubule stability, such as glutamylation, are regulated by synaptic activity (Maas et al., 2009).

In our case, the results argue for a relative specific calciumdependent mechanism, because redistribution of EB3 depends on calcium-dependent signaling pathways specifically through NR2B-containing NMDA receptors. The precise functional difference between the NR2A- and NR2B-NMDA receptor subtypes is mostly unknown. Differential and even opposing actions on NMDA receptor synaptic targeting (Tovar and Westbrook, 1999), AMPA receptor recycling (Kim et al., 2005), and synaptic plasticity (Liu et al., 2004) have been reported, but consensus is hitherto lacking (Lau and Zukin, 2007). It is, however, recognized that the divergent C-terminal tails of the NR2 subunits associate with distinct sets of signaling proteins and are crucial for activating different downstream signaling pathways (Ryan and Grant, 2009). Therefore, the different effects of NR2 subunits on microtubule dynamics in dendrites probably reflect the different local signaling pathways activated by these subunits (Sheng and Kim, 2002; Vanhoutte and Bading, 2003; Lau and Zukin, 2007). Additional studies are needed to determine which specific NR2B receptor-activated signaling complexes regulate microtubule dynamics in dendrites.

\section{Stable MAP2-decorated microtubules trap EB3}

We have also shown that, several minutes after the loss of EB3 comets from microtubule plus-ends induced by NMDA receptor activation, EB3 accumulates along MAP2-positive microtubule bundles. Moreover, MAP2 directly interacts with EB3 and is required for the observed redistribution of EB3 along the dendritic microtubules. Although EB3 and MAP2 are both abundantly present in neuronal dendrites and also both interact with microtubules, they do not display significant colocalization in basal conditions (Fig. 1) (Jaworski et al., 2009). Rather, they associate with two separate populations of microtubules. MAP2 localizes to stable microtubules and is believed to also contribute to microtubule stability, through microtubule binding and bundling. MAP2 is a substrate for many protein kinases and phosphatases, and various signaling mechanisms are known to influence MAP2 function (Sánchez et al., 2000; Cassimeris and Spittle, 2001; Dehmelt and Halpain, 2005). EB3, however, localizes to the growing plus-ends of microtubules and typically promotes persistent microtubule growth by suppressing microtubule catastrophes (Komarova et al., 2009). In addition, EB proteins are essential for the microtubule plus-end tracking of many other plus tips (Akhmanova and Steinmetz, 2008) and for the spatial regulation of certain immobile targets, such as p140Cap in spines (Jaworski et al., 2009).

The precise role of the remarkable EB3 redistribution to stable MAP2-decorated microtubules remains unresolved. It is tempting to speculate that recruitment of EB3 to MAP2-decorated mi- 
crotubules partially depletes the soluble pool of EB3 available to decorate growing MT plus tips. In that case, MAP2 acts as a sink that traps EB3 along the microtubule lattice and reduces the concentration of free EB3 available to promote growth of dynamic microtubules, required for spine maintenance. Alternatively, EB3 recruitment to MAP2-positive microtubules might serve to recruit some of the numerous EB3-interacting proteins and create specific signaling modules along the microtubule lattice. This would support the existing idea that MAP2-positive microtubules function as docking sites for neuronal signaling enzymes, such as PKA (protein kinase A) and phosphatase PP-1 (Illenberger et al., 1996; Lim and Halpain, 2000; Zhong et al., 2009). Our data also indicate that EB3 has a higher affinity for dephosphorylated MAP2. This is fully in line with the existing data on other known EB partners, such as APC (adenomatous polyposis coli protein), MCAK (mitotic centromere-associated kinesin), and CLASPs (cytoplasmic linker-associated proteins) - their phosphorylation inhibits binding to the $\mathrm{C}$ terminus of the $\mathrm{EB}$ proteins (Akhmanova and Steinmetz, 2008). Finally, changes in microtubule modifications and microtubule dynamics could also affect intracellular transport. It has been shown that molecular motor proteins are able to select subsets of microtubules and segregate membrane trafficking events between stable and dynamic microtubule populations (Cai et al., 2009). Eliminating dynamic microtubules and/or decorating MAP2 microtubules with EB3 proteins after NMDA receptor activation might therefore directly influence postsynaptic cargo trafficking.

The effect of cytoskeletal changes on spine morphology

It is widely believed that changes in dendritic spine morphology are correlated with the strength of excitatory synaptic connections in the brain (Holtmaat and Svoboda, 2009; Yoshihara et al., 2009; Wang and Zhou, 2010). Such changes in the shape and size of dendritic spines depend on remodeling of its underlying actin cytoskeleton (Hotulainen and Hoogenraad, 2010). Indeed, many reports document the close relationship between NMDA receptor activation and the modulation of actin dynamics and actin-associated proteins in spines (Halpain et al., 1998; Nägerl et al., 2004; Zhou et al., 2004). Here, we show that transient NMDA receptor activation suppresses microtubule dynamics in dendrites and prevents microtubule entry into spines. Several studies have demonstrated that intracellular calcium concentration returns to baseline levels within minutes after washout of $50 \mu \mathrm{M}$ NMDA (Randall and Thayer, 1992). The EB3 redistribution and sustained


Figure 10. $\mathrm{MAP2}$ is required for EB3 relocalization. $\boldsymbol{A}$, Representative images of hippocampal neurons cotransfected at DIV13 with $\beta$-galactosidase and control pSuper vector or pSuper-MAP2-shRNA\#2 for $4 \mathrm{~d}$, untreated or stimulated with $50 \mu \mathrm{m}$ NMDA for 5 and 25 min washout, fixed with methanol, and stained with rabbit EB3 antibody (red). Scale bar, $10 \mu \mathrm{m} . \boldsymbol{B}, \boldsymbol{C}$, Quantification of the average number of EB3 dashes per $10 \mu \mathrm{m}$ dendrite $(\boldsymbol{B})$ and the length of the EB3 stretches (in micrometers) in dendrites $(\boldsymbol{C})$ in hippocampal neurons under indicated conditions. Graph shows mean \pm SEM.

suppression of microtubule growth reported here greatly outlast the duration of NMDA receptor activation and subsequent increase in calcium levels as microtubule dynamics in dendritic shafts and spines were suppressed for at least $1 \mathrm{~h}$ after NMDA receptor activation (data not shown). This raises the intriguing possibility that dendritic microtubules directly function in long-term plasticity and contribute to the persistence of LTD. 

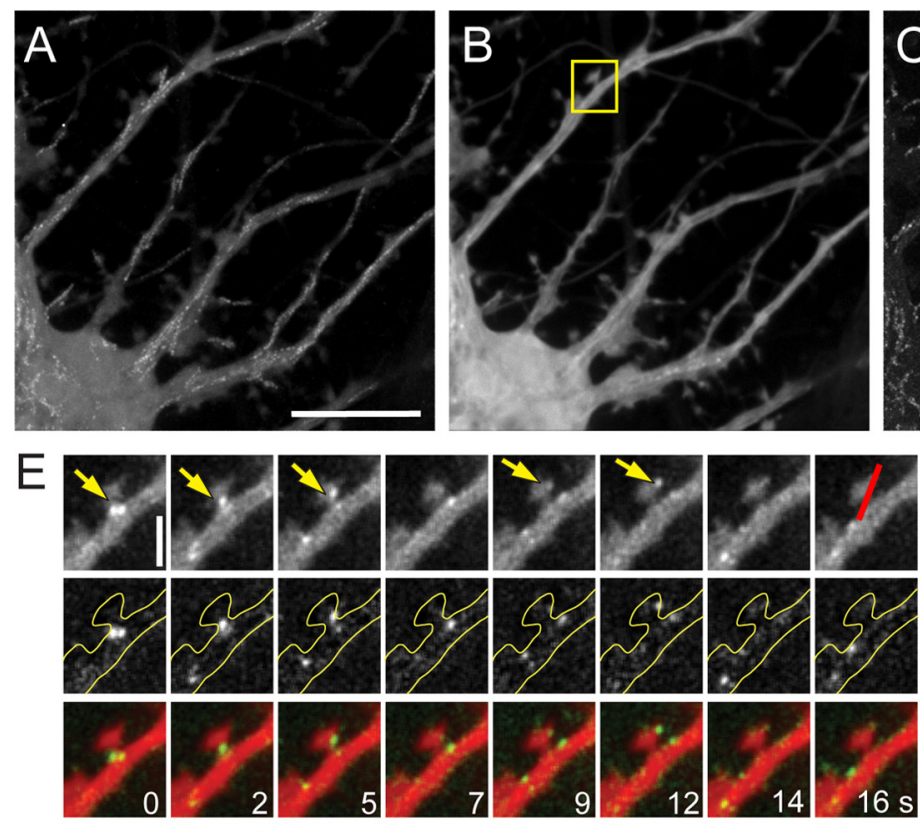

\NMDA

$\mathrm{H}$
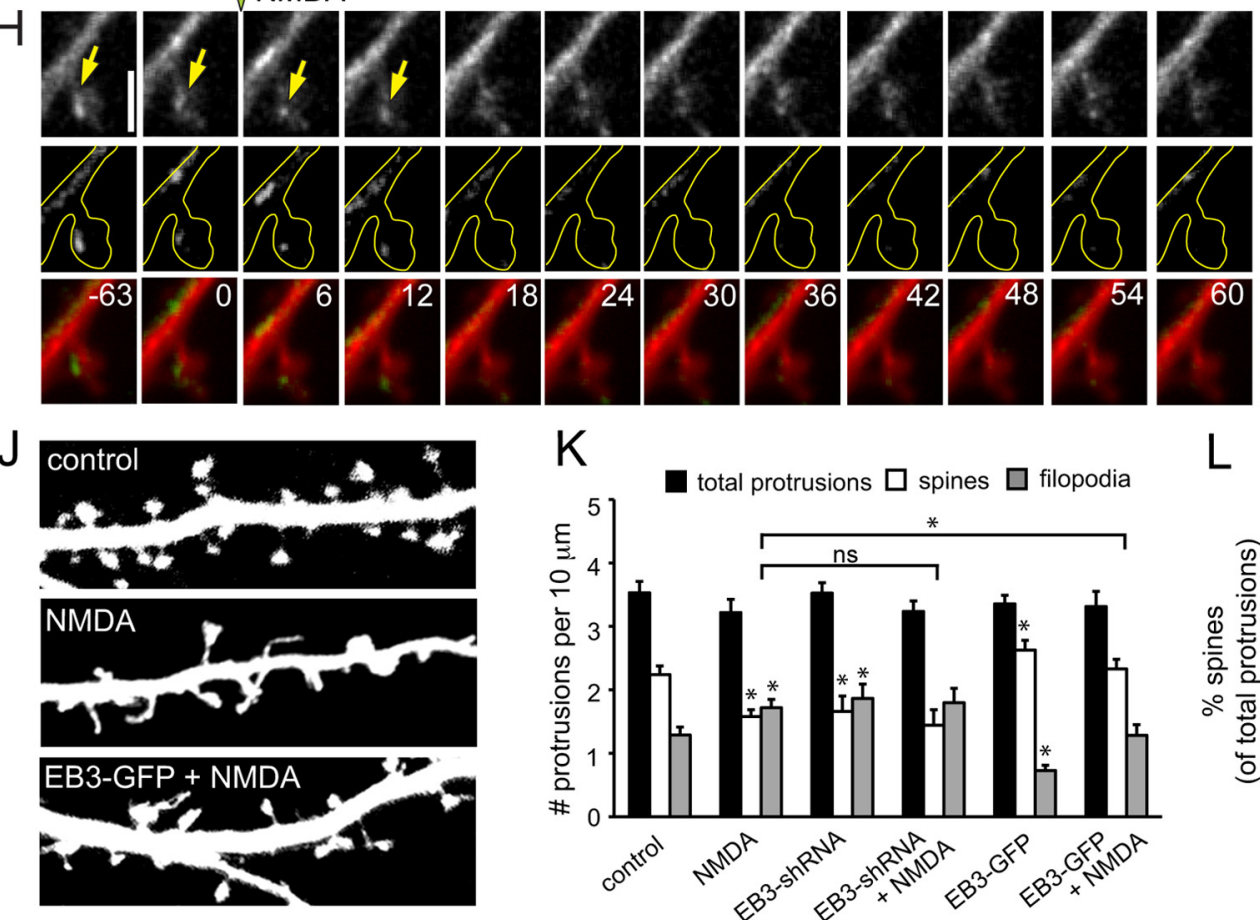

L

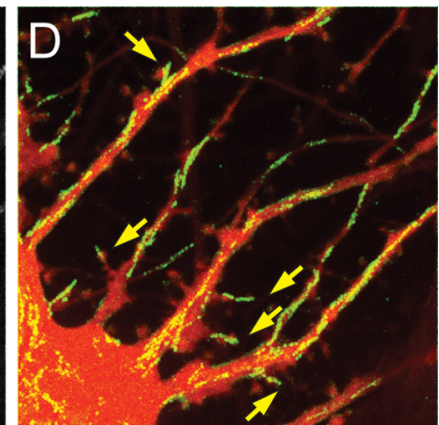

G
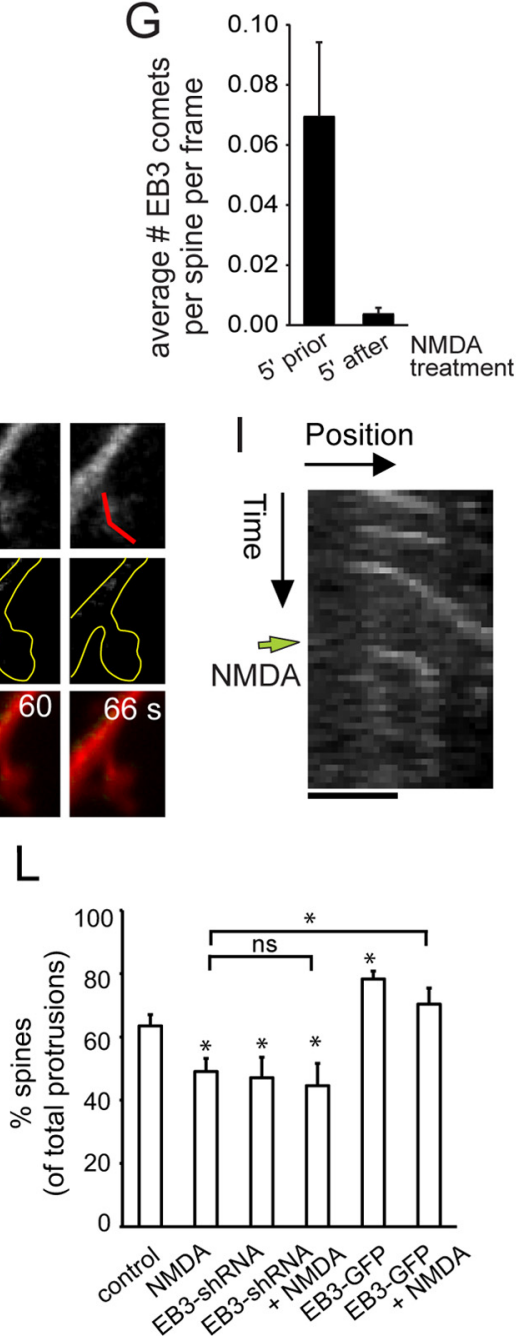

Figure 11. NMDA inhibits EB3 entry in dendritic spines. $A-D$, Time series of hippocampal neurons expressing EB3-GFP acquired with a spinning disk confocal microscope. $A$, Maximum projection of the low-pass-filtered time-lapse recording. $\boldsymbol{B}$, Average projection of the time-lapse recording used to obtain an approximate background (noncomet) fluorescence image. $\boldsymbol{C}$, Maximum projection of the time series obtained by subtracting the average projection (shown in $\boldsymbol{B}$ ) from the original, low-pass-filtered, time series. EB3 comet spine entry events are now readily detectable. $\boldsymbol{D}$, Merge of $\boldsymbol{B}$ (red) and $\boldsymbol{C}$ (green). Scale bar, $10 \mu \mathrm{m}$. For more details, see Kapitein et al. (2010). $\boldsymbol{E}$, Sequential images of the dendritic region shown in $\boldsymbol{B}$. The top row shows the original, low-pass-filtered data. The second row displays frames obtained by subtracting the average fluorescence shown in $\boldsymbol{B}$. The third row shows the merge of average and average-subtracted stills. The yellow arrows indicate comets entering the spine. Scale bar, $2 \mu \mathrm{m}$. $\boldsymbol{F}$, Kymograph over the total time-lapse 3:23 (min:sec) recording for the red line shown in $\boldsymbol{E}$. Scale bar, $1 \mu \mathrm{m}$. $\boldsymbol{G}$, Average number of EB3 comets per spine per frame during 5 min before and after addition of $50 \mu \mathrm{M} \mathrm{NMDA} \mathrm{(} N=3$ different neurons). Error bars indicate SEM. $\boldsymbol{H}$, Sequential images of a EB3-GFP-expressing neuron before and after NMDA treatment. The top row shows frames of the low-pass-filtered time series. The second row displays frames obtained by subtracting the average projection from the low-pass-filtered time series. The third row represents the merge of the average projection and images of the second row. The green arrow indicates the time point at which $50 \mu \mathrm{M}$ NMDA is added $\left(t=0\right.$ s). $\boldsymbol{I}$, Kymograph over the total time-lapse recording 2:09 (min:sec) from the red region in $\boldsymbol{H}$. After addition of NMDA (green arrow), spine entry of EB3 comets is no longer visible. Spines, $5^{\prime}$ (5 min) NMDA and 25' washout.J, Representative high-magnification images of dendrites of hippocampal neurons cotransfected at DIV13 for $4 \mathrm{~d}$ with $\beta$-galactosidase (to mark dendrite and spine morphology) and either pSuper control vector, pSuper-EB3-shRNA, or EB3-GFP, and untreated or treated with $50 \mu \mathrm{M}$ NMDA for 5 min, returned to the original medium, and subsequently fixed after $25 \mathrm{~min} . \boldsymbol{K}$, Quantification of number of protrusions per $10 \mu \mathrm{m}$ dendrites in hippocampal neurons transfected and treated as indicated. $L$, Percentage of spines of hippocampal neurons transfected and treated as indicated. Error bars indicate SEM. ${ }^{*} p<0.05 ;$ ns, not significant. 
In addition, we have shown that spine entry of EB3 labeled microtubule plus-ends protects spines against chemical LTDinduced spine shrinkage (Fig. $11 J-L$ ). This might indicate that initial LTD-inducing stimuli only affect spines devoid of microtubules. Because NMDA receptor activation affects microtubule growth inside the dendritic shaft, it could transiently decrease the microtubule content of neighboring spines and enhance their response to subsequent NMDA receptor stimulation. These mechanisms could contribute to so-called clustered plasticity, which means that similar long-term synaptic changes are more likely to occur at spines that are clustered on one dendritic branch (Govindarajan et al., 2006). Future experiments will be required to determine the in vivo importance of persistent suppression of microtubule dynamics and examine the duration of suppression required to influence long-term structural changes in the brain.

\section{Notes}

Supplemental material for this article is available at www.cellbio.nl. See link to resources for complementary videos $1-4$. This material has not been peer reviewed.

\section{References}

Akhmanova A, Steinmetz MO (2008) Tracking the ends: a dynamic protein network controls the fate of microtubule tips. Nat Rev Mol Cell Biol 9:309-322.

Aoki C, Siekevitz P (1985) Ontogenetic changes in the cyclic adenosine $3^{\prime}, 5^{\prime}$-monophosphate-stimulatable phosphorylation of cat visual cortex proteins, particularly of microtubule-associated protein 2 (MAP 2): effects of normal and dark rearing and of the exposure to light. J Neurosci 5:2465-2483.

Banker G, Goslin K, eds (1998) Culturing nerve cells. Cambridge, MA: MIT. Bear MF, Abraham WC (1996) Long-term depression in hippocampus. Annu Rev Neurosci 19:437-462.

Beattie EC, Carroll RC, Yu X, Morishita W, Yasuda H, von Zastrow M, Malenka RC (2000) Regulation of AMPA receptor endocytosis by a signaling mechanism shared with LTD. Nat Neurosci 3:1291-1300.

Berling B, Wille H, Röll B, Mandelkow EM, Garner C, Mandelkow E (1994) Phosphorylation of microtubule-associated proteins MAP2a,b and MAP2c at Ser136 by proline-directed kinases in vivo and in vitro. Eur J Cell Biol 64:120-130.

Bourne JN, Harris KM (2008) Balancing structure and function at hippocampal dendritic spines. Annu Rev Neurosci 31:47-67.

Brummelkamp TR, Bernards R, Agami R (2002) A system for stable expression of short interfering RNAs in mammalian cells. Science 296:550-553.

Cai D, McEwen DP, Martens JR, Meyhofer E, Verhey KJ (2009) Single molecule imaging reveals differences in microtubule track selection between Kinesin motors. PLoS Biol 7:e1000216.

Cassimeris L, Spittle C (2001) Regulation of microtubule-associated proteins. Int Rev Cytol 210:163-226.

Colledge M, Snyder EM, Crozier RA, Soderling JA, Jin Y, Langeberg LK, Lu H, Bear MF, Scott JD (2003) Ubiquitination regulates PSD-95 degradation and AMPA receptor surface expression. Neuron 40:595-607.

Collingridge GL, Isaac JT, Wang YT (2004) Receptor trafficking and synaptic plasticity. Nat Rev Neurosci 5:952-962.

Conde C, Cáceres A (2009) Microtubule assembly, organization and dynamics in axons and dendrites. Nat Rev Neurosci 10:319-332.

Cull-Candy S, Brickley S, Farrant M (2001) NMDA receptor subunits: diversity, development and disease. Curr Opin Neurobiol 11:327-335.

Deery WJ, Means AR, Brinkley BR (1984) Calmodulin-microtubule association in cultured mammalian cells. J Cell Biol 98:904-910.

Dehmelt L, Halpain S (2005) The MAP2/Tau family of microtubuleassociated proteins. Genome Biol 6:204.

Dehmelt L, Nalbant P, Steffen W, Halpain S (2006) A microtubule-based, dynein-dependent force induces local cell protrusions: implications for neurite initiation. Brain Cell Biol 35:39-56.

Dingledine R, Borges K, Bowie D, Traynelis SF (1999) The glutamate receptor ion channels. Pharmacol Rev 51:7-61.

Ehlers MD (2000) Reinsertion or degradation of AMPA receptors determined by activity-dependent endocytic sorting. Neuron 28:511-525.

Faddis BT, Hasbani MJ, Goldberg MP (1997) Calpain activation contrib- utes to dendritic remodeling after brief excitotoxic injury in vitro. J Neurosci 17:951-959.

Farah CA, Liazoghli D, Perreault S, Desjardins M, Guimont A, Anton A, Lauzon M, Kreibich G, Paiement J, Leclerc N (2005) Interaction of microtubule-associated protein-2 and p63: a new link between microtubules and rough endoplasmic reticulum membranes in neurons. J Biol Chem 280:9439-9449.

Fontaine-Lenoir V, Chambraud B, Fellous A, David S, Duchossoy Y, Baulieu EE, Robel P (2006) Microtubule-associated protein 2 (MAP2) is a neurosteroid receptor. Proc Natl Acad Sci U S A 103:4711-4716.

Fuller GM, Brinkley BR (1976) Structure and control of assembly of cytoplasmic microtubules in normal and transformed cells. J Supramol Struct 5:497(349)-514(366).

Govindarajan A, Kelleher RJ, Tonegawa S (2006) A clustered plasticity model of long-term memory engrams. Nat Rev Neurosci 7:575-583.

Greer PL, Greenberg ME (2008) From synapse to nucleus: calciumdependent gene transcription in the control of synapse development and function. Neuron 59:846-860.

Gu C, Zhou W, Puthenveedu MA, Xu M, Jan YN, Jan LY (2006) The microtubule plus-end tracking protein EB1 is required for Kvl voltage-gated $\mathrm{K}^{+}$channel axonal targeting. Neuron 52:803-816.

Halpain S, Greengard P (1990) Activation of NMDA receptors induces rapid dephosphorylation of the cytoskeletal protein MAP2. Neuron 5:237-246.

Halpain S, Hipolito A, Saffer L (1998) Regulation of F-actin stability in dendritic spines by glutamate receptors and calcineurin. J Neurosci 18:9835-9844.

Hardingham GE, Fukunaga Y, Bading H (2002) Extrasynaptic NMDARs oppose synaptic NMDARs by triggering CREB shut-off and cell death pathways. Nat Neurosci 5:405-414.

He Y, Yu W, Baas PW (2002) Microtubule reconfiguration during axonal retraction induced by nitric oxide. J Neurosci 22:5982-5991.

Hering H, Sheng M (2003) Activity-dependent redistribution and essential role of cortactin in dendritic spine morphogenesis. J Neurosci 23:11759-11769.

Hollmann M, Heinemann S (1994) Cloned glutamate receptors. Annu Rev Neurosci 17:31-108.

Holtmaat A, Svoboda K (2009) Experience-dependent structural synaptic plasticity in the mammalian brain. Nat Rev Neurosci 10:647-658.

Hoogenraad CC, Akhmanova A (2010) Dendritic spine plasticity: new regulatory roles of dynamic microtubules. Neuroscientist 16:650-661.

Hoogenraad CC, Bradke F (2009) Control of neuronal polarity and plasticity —a renaissance for microtubules? Trends Cell Biol 19:669-676.

Hoogenraad CC, Milstein AD, Ethell IM, Henkemeyer M, Sheng M (2005) GRIP1 controls dendrite morphogenesis by regulating EphB receptor trafficking. Nat Neurosci 8:906-915.

Horne EA, Dell'Acqua ML (2007) Phospholipase C is required for changes in postsynaptic structure and function associated with NMDA receptordependent long-term depression. J Neurosci 27:3523-3534.

Hoskison MM, Yanagawa Y, Obata K, Shuttleworth CW (2007) Calciumdependent NMDA-induced dendritic injury and MAP2 loss in acute hippocampal slices. Neuroscience 145:66-79.

Hotulainen P, Hoogenraad CC (2010) Actin in dendritic spines: connecting dynamics to function. J Cell Biol 189:619-629.

Hu X, Viesselmann C, Nam S, Merriam E, Dent EW (2008) Activitydependent dynamic microtubule invasion of dendritic spines. J Neurosci 28:13094-13105.

Illenberger S, Drewes G, Trinczek B, Biernat J, Meyer HE, Olmsted JB, Mandelkow EM, Mandelkow E (1996) Phosphorylation of microtubuleassociated proteins MAP2 and MAP4 by the protein kinase p110mark. Phosphorylation sites and regulation of microtubule dynamics. J Biol Chem 271:10834-10843.

Jaworski J, Hoogenraad CC, Akhmanova A (2008) Microtubule plus-end tracking proteins in differentiated mammalian cells. Int J Biochem Cell Biol 40:619-637.

Jaworski J, Kapitein LC, Gouveia SM, Dortland BR, Wulf PS, Grigoriev I, Camera P, Spangler SA, Di Stefano P, Demmers J, Krugers H, Defilippi P, Akhmanova A, Hoogenraad CC (2009) Dynamic microtubules regulate dendritic spine morphology and synaptic plasticity. Neuron 61:85-100.

Kaech S, Ludin B, Matus A (1996) Cytoskeletal plasticity in cells expressing neuronal microtubule-associated proteins. Neuron 17:1189-1199.

Kalcheva N, Albala JS, Binder LI, Shafit-Zagardo B (1994) Localization of 
specific epitopes on human microtubule-associated protein 2. J Neurochem 63:2336-2341.

Kameyama K, Lee HK, Bear MF, Huganir RL (1998) Involvement of a postsynaptic protein kinase A substrate in the expression of homosynaptic long-term depression. Neuron 21:1163-1175.

Kapitein LC, Yau KW, Hoogenraad CC (2010) Microtubule dynamics in dendritic spines. Methods Cell Biol 97:111-132.

Kennedy MB, Beale HC, Carlisle HJ, Washburn LR (2005) Integration of biochemical signalling in spines. Nat Rev Neurosci 6:423-434.

Kim MJ, Dunah AW, Wang YT, Sheng M (2005) Differential roles of NR2Aand NR2B-containing NMDA receptors in Ras-ERK signaling and AMPA receptor trafficking. Neuron 46:745-760.

Komarova Y, Lansbergen G, Galjart N, Grosveld F, Borisy GG, Akhmanova A (2005) EB1 and EB3 control CLIP dissociation from the ends of growing microtubules. Mol Biol Cell 16:5334-5345.

Komarova Y, De Groot CO, Grigoriev I, Gouveia SM, Munteanu EL, Schober JM, Honnappa S, Buey RM, Hoogenraad CC, Dogterom M, Borisy GG, Steinmetz MO, Akhmanova A (2009) Mammalian end binding proteins control persistent microtubule growth. J Cell Biol 184:691-706.

Krichevsky AM, Kosik KS (2002) RNAi functions in cultured mammalian neurons. Proc Natl Acad Sci U S A 99:11926-11929.

Lau CG, Zukin RS (2007) NMDA receptor trafficking in synaptic plasticity and neuropsychiatric disorders. Nat Rev Neurosci 8:413-426.

Lee HK, Kameyama K, Huganir RL, Bear MF (1998) NMDA induces longterm synaptic depression and dephosphorylation of the GluR1 subunit of AMPA receptors in hippocampus. Neuron 21:1151-1162.

Lee YC, Wolff J (1982) Two opposing effects of calmodulin on microtubule assembly depend on the presence of microtubule-associated proteins. J Biol Chem 257:6306-6310.

Lim RW, Halpain S (2000) Regulated association of microtubule-associated protein 2 (MAP2) with Src and Grb2: evidence for MAP2 as a scaffolding protein. J Biol Chem 275:20578-20587.

Liu L, Wong TP, Pozza MF, Lingenhoehl K, Wang Y, Sheng M, Auberson YP, Wang YT (2004) Role of NMDA receptor subtypes in governing the direction of hippocampal synaptic plasticity. Science 304:1021-1024.

Lu W, Man H, Ju W, Trimble WS, MacDonald JF, Wang YT (2001) Activation of synaptic NMDA receptors induces membrane insertion of new AMPA receptors and LTP in cultured hippocampal neurons. Neuron 29:243-254.

Maas C, Belgardt D, Lee HK, Heisler FF, Lappe-Siefke C, Magiera MM, van Dijk J, Hausrat TJ, Janke C, Kneussel M (2009) Synaptic activation modifies microtubules underlying transport of postsynaptic cargo. Proc Natl Acad Sci U S A 106:8731-8736.

Malinow R, Malenka RC (2002) AMPA receptor trafficking and synaptic plasticity. Annu Rev Neurosci 25:103-126.

Marcum JM, Dedman JR, Brinkley BR, Means AR (1978) Control of microtubule assembly-disassembly by calcium-dependent regulator protein. Proc Natl Acad Sci U S A 75:3771-3775.

Mashanov GI, Molloy JE (2007) Automatic detection of single fluorophores in live cells. Biophys J 92:2199-2211.

Matsuzaki M, Honkura N, Ellis-Davies GC, Kasai H (2004) Structural basis of long-term potentiation in single dendritic spines. Nature 429:761-766.

Mimori-Kiyosue Y, Shiina N, Tsukita S (2000) The dynamic behavior of the APC-binding protein EB1 on the distal ends of microtubules. Curr Biol $10: 865-868$.

Montoro RJ, Díaz-Nido J, Avila J, López-Barneo J (1993) N-Methyl-Daspartate stimulates the dephosphorylation of the microtubule-associated protein 2 and potentiates excitatory synaptic pathways in the rat hippocampus. Neuroscience 54:859-871.

Nägerl UV, Eberhorn N, Cambridge SB, Bonhoeffer T (2004) Bidirectional activity-dependent morphological plasticity in hippocampal neurons. Neuron 44:759-767.

Okamoto K, Nagai T, Miyawaki A, Hayashi Y (2004) Rapid and persistent modulation of actin dynamics regulates postsynaptic reorganization underlying bidirectional plasticity. Nat Neurosci 7:1104-1112.

Olmsted JB, Borisy GG (1975) Ionic and nucleotide requirements for microtubule polymerization in vitro. Biochemistry 14:2996-3005.

Park M, Penick EC, Edwards JG, Kauer JA, Ehlers MD (2004) Recycling endosomes supply AMPA receptors for LTP. Science 305:1972-1975.
Park M, Salgado JM, Ostroff L, Helton TD, Robinson CG, Harris KM, Ehlers MD (2006) Plasticity-induced growth of dendritic spines by exocytic trafficking from recycling endosomes. Neuron 52:817-830.

Philpot BD, Lim JH, Halpain S, Brunjes PC (1997) Experience-dependent modifications in MAP2 phosphorylation in rat olfactory bulb. J Neurosci 17:9596-9604.

Quinlan EM, Halpain S (1996) Postsynaptic mechanisms for bidirectional control of MAP2 phosphorylation by glutamate receptors. Neuron 16:357-368.

Randall RD, Thayer SA (1992) Glutamate-induced calcium transient triggers delayed calcium overload and neurotoxicity in rat hippocampal neurons. J Neurosci 12:1882-1895.

Rose J, Jin SX, Craig AM (2009) Heterosynaptic molecular dynamics: locally induced propagating synaptic accumulation of CaM kinase II. Neuron 61:351-358.

Ryan TJ, Grant SG (2009) The origin and evolution of synapses. Nat Rev Neurosci 10:701-712.

Sánchez C, Díaz-Nido J, Avila J (2000) Phosphorylation of microtubuleassociated protein 2 (MAP2) and its relevance for the regulation of the neuronal cytoskeleton function. Prog Neurobiol 61:133-168.

Schliwa M (1976) The role of divalent cations in the regulation of microtubule assembly. In vivo studies on microtubules of the heliozoan axopodium using the ionophore A23187. J Cell Biol 70:527-540.

Schliwa M, Euteneuer U, Bulinski JC, Izant JG (1981) Calcium lability of cytoplasmic microtubules and its modulation by microtubule-associated proteins. Proc Natl Acad Sci U S A 78:1037-1041.

Shaner NC, Campbell RE, Steinbach PA, Giepmans BN, Palmer AE, Tsien RY (2004) Improved monomeric red, orange and yellow fluorescent proteins derived from Discosoma sp. red fluorescent protein. Nat Biotechnol 22:1567-1572.

Sheng M, Kim MJ (2002) Postsynaptic signaling and plasticity mechanisms. Science 298:776-780.

Shepherd JD, Huganir RL (2007) The cell biology of synaptic plasticity: AMPA receptor trafficking. Annu Rev Cell Dev Biol 23:613-643.

Stepanova T, Slemmer J, Hoogenraad CC, Lansbergen G, Dortland B, De Zeeuw CI, Grosveld F, van Cappellen G, Akhmanova A, Galjart N (2003) Visualization of microtubule growth in cultured neurons via the use of EB3-GFP (end-binding protein 3-green fluorescent protein). J Neurosci 23:2655-2664.

Strömberg E, Wallin M (1994) Differences in the effect of $\mathrm{Ca}^{2+}$ on isolated microtubules from cod and cow brain. Cell Motil Cytoskeleton 28:59-68.

Takemura R, Okabe S, Umeyama T, Kanai Y, Cowan NJ, Hirokawa N (1992) Increased microtubule stability and alpha tubulin acetylation in cells transfected with microtubule-associated proteins MAP1B, MAP2 or tau. J Cell Sci 103:953-964.

Tapia R, Medina-Ceja L, Peña F (1999) On the relationship between extracellular glutamate, hyperexcitation and neurodegeneration, in vivo. Neurochem Int 34:23-31.

Tovar KR, Westbrook GL (1999) The incorporation of NMDA receptors with a distinct subunit composition at nascent hippocampal synapses in vitro. J Neurosci 19:4180-4188.

Vanhoutte P, Bading H (2003) Opposing roles of synaptic and extrasynaptic NMDA receptors in neuronal calcium signalling and BDNF gene regulation. Curr Opin Neurobiol 13:366-371.

Wang XB, Zhou Q (2010) Spine remodeling and synaptic modification. Mol Neurobiol 41:29-41.

Wilm M, Shevchenko A, Houthaeve T, Breit S, Schweigerer L, Fotsis T, Mann M (1996) Femtomole sequencing of proteins from polyacrylamide gels by nano-electrospray mass spectrometry. Nature 379:466-469.

Wong RO, Ghosh A (2002) Activity-dependent regulation of dendritic growth and patterning. Nat Rev Neurosci 3:803-812.

Yoshihara Y, De Roo M, Muller D (2009) Dendritic spine formation and stabilization. Curr Opin Neurobiol 19:146-153.

Zhong H, Sia GM, Sato TR, Gray NW, Mao T, Khuchua Z, Huganir RL, Svoboda K (2009) Subcellular dynamics of type II PKA in neurons. Neuron 62:363-374.

Zhou Q, Homma KJ, Poo MM (2004) Shrinkage of dendritic spines associated with long-term depression of hippocampal synapses. Neuron 44: $749-757$. 